University of Nebraska - Lincoln

DigitalCommons@University of Nebraska - Lincoln

2011

Influence of Karst Landscape on Planetary Boundary Layer

Atmosphere: A Weather Research and Forecasting (WRF)

Model-Based Investigation

Ronnie Leeper

Rezaul Mamood

Arturo I. Quintanar

Follow this and additional works at: https://digitalcommons.unl.edu/hprccpubs

Part of the Atmospheric Sciences Commons, Climate Commons, Environmental Indicators and Impact Assessment Commons, Environmental Monitoring Commons, Fresh Water Studies Commons, Hydrology Commons, Meteorology Commons, Natural Resources Management and Policy Commons, Sustainability Commons, and the Water Resource Management Commons

This Article is brought to you for free and open access by the High Plains Regional Climate Center at DigitalCommons@University of Nebraska - Lincoln. It has been accepted for inclusion in HPRCC Personnel Publications by an authorized administrator of DigitalCommons@University of Nebraska - Lincoln. 


\title{
Influence of Karst Landscape on Planetary Boundary Layer Atmosphere: A Weather Research and Forecasting (WRF) Model-Based Investigation
}

\author{
RONNIE LEEPER \\ Department of Geography and Geology and Kentucky Climate Center, Western Kentucky University, \\ Bowling Green, Kentucky \\ REZAUl MAHMOOD \\ Meteorology Program, Department of Geography and Geology and Kentucky Climate Center, Western Kentucky University, \\ Bowling Green, Kentucky \\ ARTURO I. QUINTANAR \\ Department of Geography and Geology and Kentucky Climate Center, Western Kentucky University, \\ Bowling Green, Kentucky
}

(Manuscript received 29 December 2009, in final form 26 December 2010)

\begin{abstract}
Karst hydrology provides a unique set of surface and subsurface hydrological components that affect soil moisture variability. Over karst topography, surface moisture moves rapidly below ground via sink holes, vertical shafts, and sinking streams, reducing surface runoff and moisture infiltration into the soil. In addition, subsurface cave blockage or rapid snowmelt over karst can lead to surface flooding. Moreover, regions dominated by karst may exhibit either drier or wetter soils when compared to nonkarst landscape. However, because of the lack of both observational soil moisture datasets to initialize simulations and regional land surface models (LSMs) that include explicit karst hydrological processes, the impact of karst on atmospheric processes is not fully understood. Therefore, the purpose of this study was to investigate the importance of karst hydrology on planetary boundary layer (PBL) atmosphere using the Weather Research and Forecasting Model (WRF). This research is a first attempt to identify the impacts of karst on PBL. To model the influence of karst hydrology on atmospheric processes, soil moisture was modified systematically over the Western Kentucky Pennyroyal Karst (WKYPK) region to produce an ensemble of dry and wet anomaly experiments. Simulations were conducted for both frontal- and nonfrontal-based convection. For the dry ensemble, cloud cover was both diminished downwind of karst because of reduced atmospheric moisture and enhanced slightly upwind as moist air moved into a region of increased convection compared to control simulations (CTRL). Moreover, sensible (latent) heat flux and PBL heights were increased (decreased) compared to CTRL. In addition, the wet ensemble experiments reduced PBL heights and sensible heat flux and increased cloud cover over karst compared to CTRL. Other changes were noted in equivalent potential temperature $\left(\theta_{e}\right)$ and vertical motions and development of new mesoscale circulation cells with alterations in soil moisture over WKYPK. Finally, the location of simulated rainfall patterns were altered by both dry and wet ensembles with the greatest sensitivity to simulated rainfall occurring during weakly forced or nonfrontal cases. Simulated rainfall for the dry ensemble was more similar to the North American Regional Reanalysis (NARR) than CTRL for the nonfrontal case. Furthermore, the initial state of the atmosphere and convective triggers were found to either enhance or diminish simulated atmospheric responses.
\end{abstract}

Corresponding author address: Rezaul Mahmood, Meteorology Program, Department of Geography and Geology and Kentucky Climate Center, Western Kentucky University, 1906 College Heights Blvd., Bowling Green, KY 42101.

E-mail: rezaul.mahmood@wku.edu

\section{Introduction}

Karst topography is a culmination of many geological and hydrological processes. This well-recognized geomorphologic landscape can be found across the globe. Karst forms over areas underlined by soluble bedrock 


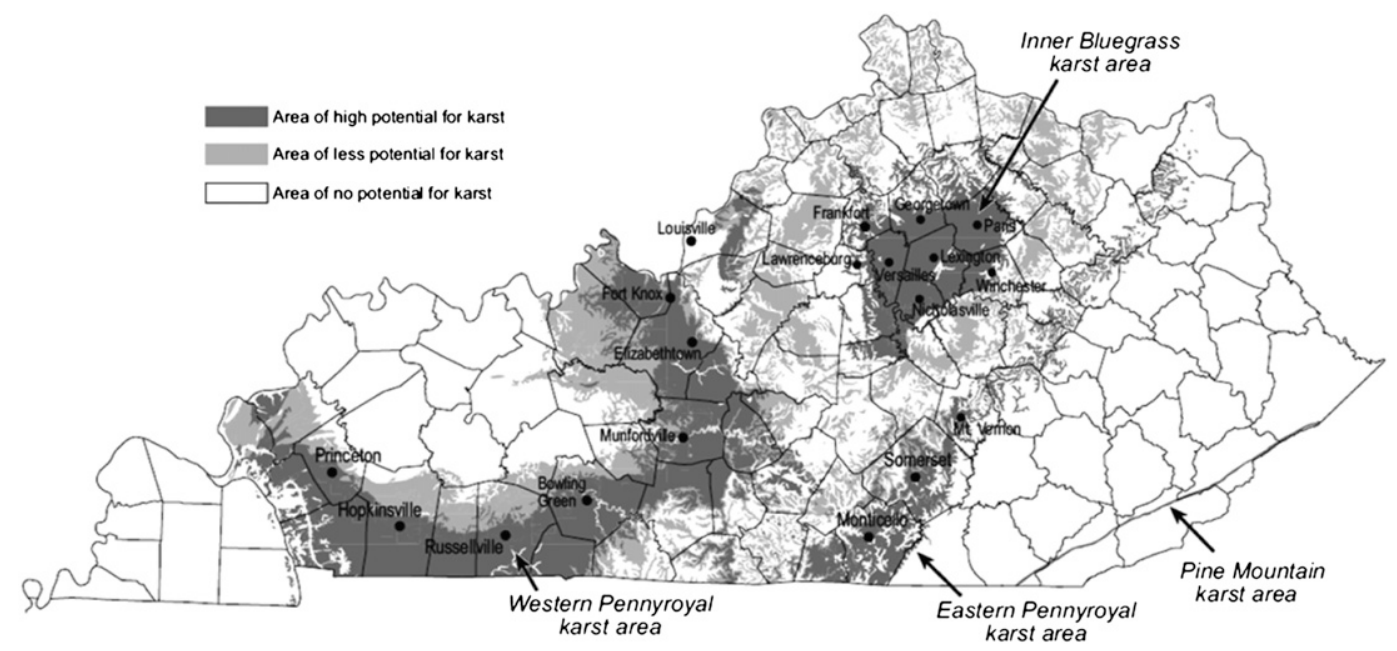

FIG. 1. Karst regions across KY. The soil moisture was varied in the WKYPK area for this studies' simulation-sensitivity experiments. Source: Currens (2002).

such as marble, gypsum, salt, dolomite, and limestone by a process known as karstification (Milanović 1981; Veni et al. 2001). Through this continuous process, infiltrated rainwater and underground moisture move through the root zone mixing with $\mathrm{CO}_{2}$ and forming carbonic acid that eventually dissolves away underlying bedrock (Milanović 1981). Over a period of time, karst surface features will emerge as sink holes, vertical shafts, and subterranean river systems through the dissolution of the region's bedrock, which can significantly alter localized drainage patterns and hydrological processes. The altered hydrological processes in turn affect planetary boundary layer (PBL) development, distribution of moisture and energy at the surface, convection, and precipitation (e.g., McPherson 2007).

Karst affects the overall periodicity of the hydrological cycle by impacting the movement of moisture between the earth's surface and atmosphere (Hess et al. 1989; De Vries and Simmers 2002; Goldscheider et al. 2007). Karst topography is typically described as well drained (Groves et al. 2005; Polk 2010) and can reduce evapotranspiration rates (Crowther 1987; Hess and White 1989a). However, this also increases the water table's sensitivity to hydrological events, which has been known to induce flash flooding in low-lying areas and saturate soils after a heavy rain event or melting snowpack (Milanović 1981). Moreover, karst topography, through its effect on local hydrology, can significantly and heterogeneously alter soil moisture distribution, which can establish important feedbacks between karst and nearsurface atmosphere.

Despite our conceptual understanding of the link between karst and atmosphere, limited research has been devoted to this topic primarily for three reasons.
First, the current focus of karst research communities is groundwater sustainability practices that mitigate the anthropogenic impact (Veni et al. 2001), which limits collaboration between atmospheric and hydrological communities. Second, the inaccessibility of most subsurface karst systems around the world has made the development of an adequate karst dataset necessary to model a karst aquifer difficult (Groves 2008; White 2002). Third, current land surface models (LSMs) were designed with a level of generality to operate effectively across a broad spectrum of land surfaces of the world (Pitman 2003) and have difficulties in parameterizing localized hydrological processes such as karst. These three factors, along with complexity of the karst environment, made modeling challenging (White 2002). However, as computational capabilities have improved over the years along with our ability to simulate atmospheric processes at finer resolutions, the importance of localized hydrological features such as karst have become increasingly more important. This provided impetus for the inclusion of karst as a local hydrologic feature in atmospheric modeling research to reflect current empirical and conceptual understanding of land surface-atmosphere interactions.

The purpose of this research was to investigate the significance of karst hydrology—particularly, karst soil moisture (SM) —on atmospheric processes. Specifically, to understand the impacts of karst hydrology on PBL atmosphere and convective rainfall, the Weather Research and Forecasting Model (WRF) was applied for four convective events. A series of 24-h long simulations were conducted for this purpose and SM was perturbed during these events only over a well-known karst region of western Kentucky (Fig. 1). This is referred to here as 

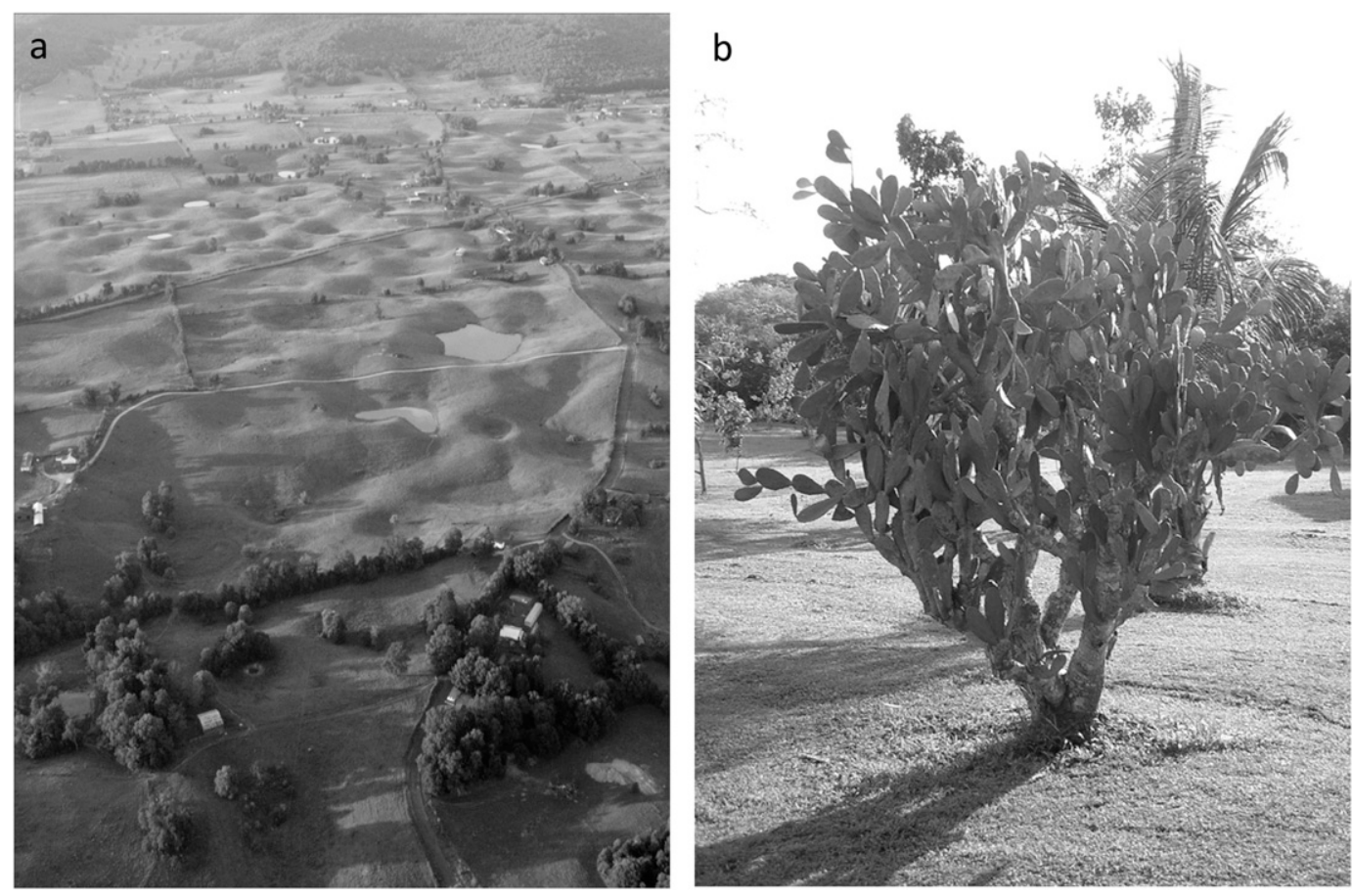

FIG. 2. Images of (a) a sink hole flood plain over WKYPK (source: G. Berdaux 2010, personal communication) and (b) a cactus in Belize (source: J. S. Polk 2010, personal communication).

Western Kentucky Pennyroyal Karst (WKYPK; Fig. 1). The WKYPK includes the world's longest cave system (the Mammoth Cave) (White 1989; Currens 2002) and is dotted with thousands of sinkholes (Fig. 2a).

\section{Background}

As noted above, karst landscape contains underground water passages within the bedrock developed through karstification (Milanović 1981; Veni et al. 2001) and this allows rapid movement of water through the karst topography. Over nonkarst terrain, precipitation is either evaporated, infiltrated, or moves along the surface as runoff. Conversely, over well-developed karst topography there is limited runoff since much of the precipitation is rapidly infiltrated or injected directly into the karst aquifer (below ground) via sink holes and vertical shafts (Crowther 1987; Hess and White 1989b; Groves 2007). For example, J. S. Polk (2010, personal communication) noted that soils over portions of Belize are so well drained from karst that cacti dominate the landscape (Fig. 2b) despite an annual rainfall of ranges between 1500 (60 in.) and $4000 \mathrm{~mm}$ (160 in.). Although we do not have these side-by-side observations, other hydrological-hydrometeorological measurements over WKYPK could provide insight that would allow us to understand potential dynamics of soil moisture (i.e., dryness and wetness) over karst areas. Groves et al. (2005) set up instruments on the surface and in a cave in WKYPK and was able to capture surface rainfall in the cave within $30-45$ min of observed precipitation. This is a clear indication of rapid transport of surface moisture into a karst aquifer. Moreover, a literature survey clearly shows that karst areas may experience severe soil moisture dryness because of rapid drainage associated with geomorphologic conditions (Wang et al. 2004; Polk 2009; Polk et al. 2007; Ewe et al. 1999; Crowther 1987; Daoxian 1988).

Estimations of evapotranspiration (ET) over karst terrain by the Hess and White (1989b) 35-year water balance study were $10 \%-13 \%$ less than those found over nonkarst topography. This was presumably from relatively rapid surface drainage and reduced soil infiltration (Hess and White 1989b). Similar results were found from Crowther (1987) over tropical karst regions. In addition, soils over karst topography could be subjected to flooding from below as a result of a rising water table, which becomes increasingly sensitive to hydrological events as karst develops (Milanović 1981). Milanović (1981) observed karstic water tables varying by as much as $100 \mathrm{~m}$ after a rain event or melting snowpack that could cause localized flooding and increase atmospheric moisture availability within the root zone. Based on these findings, it is expected that local hydrology can lead to 
contrasts in SM and ET rates between karst and adjacent nonkarst topographies.

It has been shown that the availability of SM has profound effects on PBL processes by influencing potential evaporation and subsequent partitioning of available energy at the surface (McCumber and Pielke 1981; Chen and Avissar 1994; LeMone et al. 2007). Partitioning of moisture and energy at the surface greatly affects PBL temperature, convection, stability, and precipitation (Zhang and Anthes 1982; Chen and Avissar 1994; Clark and Arritt 1995; Pan et al. 1996; Pielke 2001; Findell and Eltahir 2003; Quintanar et al. 2008, 2009). Clark and Arritt (1995) found that increased SM delayed the onset of precipitation but enhanced total accumulation through local moisture recycling, creating a positive feedback to precipitation. Brubaker et al. (1993) identified that local moisture recycling accounted for up to $30 \%$ of total accumulated precipitation over the Mississippi drainage basin. In addition, it was reported that gradients in SM led to differential heating at the surface through evaporative cooling and promoted the development of mesoscale circulations similar to land-sea breezes (Ookouchi et al. 1984; Chang and Wetzel 1991; Chen and Avissar 1994; Clark and Arritt 1995; McPherson 2007). These mesoscale circulations vigorously mixed the PBL more effectively than thermal or mechanically forced convection with stronger vertical velocities that tended to organize convective development and precipitation along the circulation (Ookouchi et al. 1984; Chen and Avissar 1994).

However, feedbacks between SM and the development of convection and precipitation are nonlinear (Chen and Avissar 1994; Lyons 2002; Findell and Eltahir 2003; Quintanar et al. 2008). Moist soils can enhance instability by lowering the lifted condensation level (LCL) (Brutsaert 2005), but only if some perturbation exists to initiate parcel displacement. Otherwise, moist soils create a negative feedback, inhibiting the development of convection and subsequent rainfall by reducing surface temperature and turbulent mixing within the PBL (Findell and Eltahir 2003; Pan et al. 1996). Likewise, drier soils may also result in either positive or negative feedbacks to convective development (Findell and Eltahir 2003; Pan et al. 1996). Lyons (2002) observed and modeled the preferential cloud development over drier native vegetation than over adjacent moist agricultural lands because of increased vertical mixing from convective turbulence caused by warmer surface temperatures and higher roughness length of native vegetation. Findell and Eltahir (2003) suggested that deep convection and precipitation could be initiated over both moist and dry soils depending on the initial thermodynamic structure of the atmosphere.

Proper representation of initial SM conditions in numerical models has lead to improvements in modeled forecasts of propagating drylines (Grasso 2000; Pielke 2001), modeled temperature (Huang et al. 1996; Dirmeyer et al. 2000; Schlosser and Milly 2002), and precipitation (Chang and Wetzel 1991; Clark and Arritt 1995; Douville et al. 2001). However, limited availability of observed SM data and uncertainty in the land surface data for model initialization sometimes restricts model applications for various local conditions, including karst. Despite these challenges, one of the goals of this research is to investigate the significance of karst hydrology on atmospheric PBL and convective rainfall. We would like to 1) determine if the WKYPK region is large enough to affect atmospheric processes and 2) identify the importance of local hydrological processes. To overcome the uncertainty in the karst land surface hydrology data as noted above, we have modified initial SM data to approximate karst SM conditions. This was a first attempt to explicitly represent the influence of karst in a numerical weather prediction model. It was anticipated here that karst-modified hydrology will impact atmospheric evolution and convective rainfall, and highlight WKYPK as an important local hydrological feature warranting further investigations of this type.

\section{Experimental design}

To fulfill the objectives of this research, simulations were carried out using the Weather Research and Forecast Model, version 3.1 (WRF v3.1) for a series of convective events. Simulations were conducted over WKYPK, which is uniquely suited for this study with adjacent contrasting karst and nonkarst topographies (Fig. 1) (Cubbage 1981; White 1989; Currens 2002). Despite studies that have included nonkarst aquifers in numerical atmospheric simulations [e.g., York et al. (2002), Yeh and Eltahir (2005), Gulden et al. (2007), and Jiang et al. (2009)], karst aquifers require the inclusion of the local conduit system to account for both diffuse and conduit flows (White 2002), which would require an exhaustive field campaign and was beyond the scope of this introductory study. However, to include the effect of karst hydrology in numerical simulations, initial SM conditions were perturbed only over WKYPK (Fig. 1) to understand the impacts of karst hydrology on SM variability. For this study, four convective events (11 June 2006, 17 June 2006, 23 June 2006, and 29 August 2008) were used. They represent various typical summertime atmospheric conditions and each was modeled for a 24-h period. The events were chosen based on availability of data and other ongoing research by this group (Quintanar et al. 2008, 2009).

As previously mentioned, numerical simulations were conducted using the WRF. It was developed in 


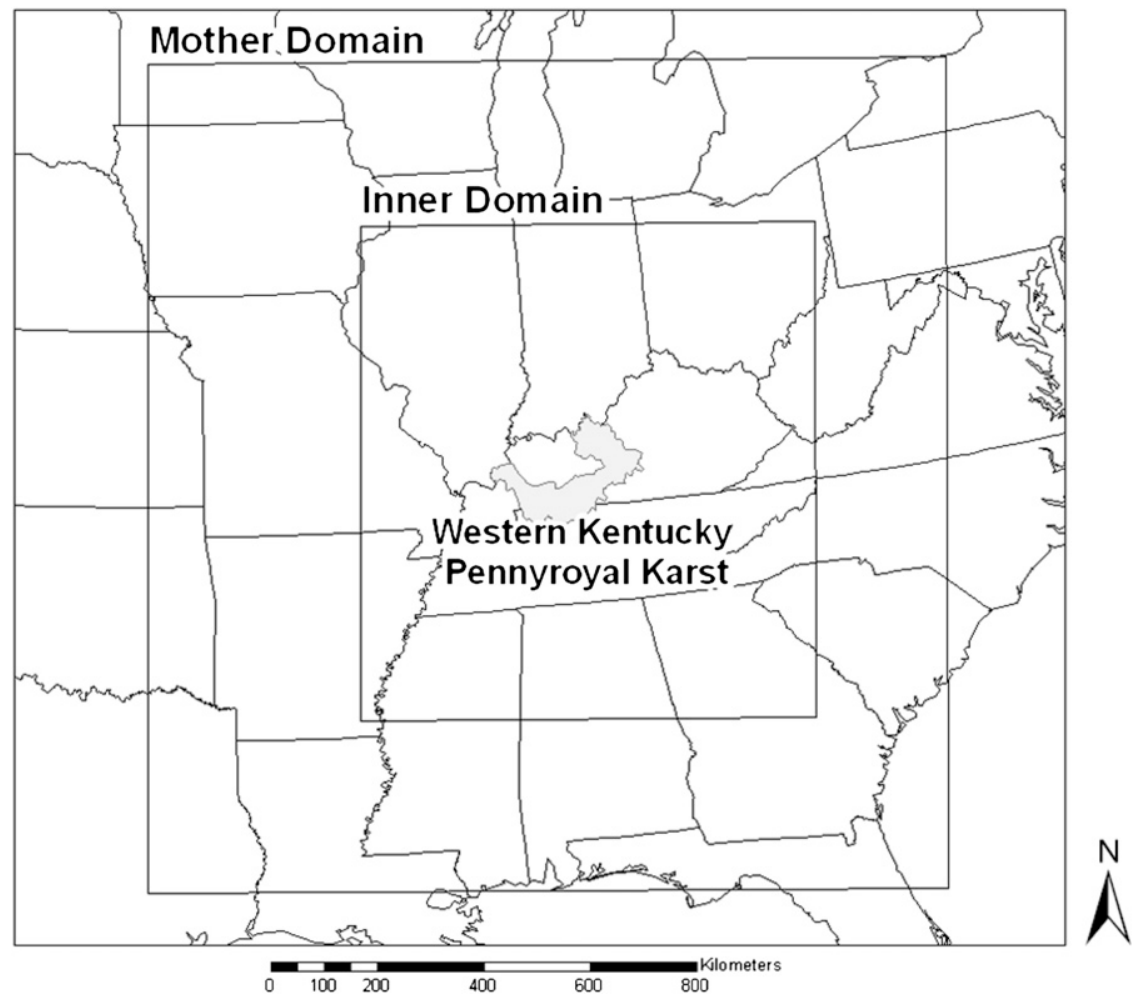

FIG. 3. Model domains used in this research along with the WKYPK region.

collaboration between the National Centers for Environmental Prediction (NCEP) and the National Center for Atmospheric Research (NCAR) (WRF 2009). The primitive equations that govern atmospheric motion within the WRF model are fully compressible, Eulerian based, nonhydrostatic, and integrated using the thirdorder Runge-Kutta scheme (WRF 2009). The WRF model supports one- and two-way nested grids with a series of microphysics, cumulus parameterization, PBL, surface layer, land surface model, radiation, and turbulent scheme options (WRF 2009). For this study, two-way nested grids were centered over western Kentucky at $37.0^{\circ} \mathrm{N}$ and $-86.5^{\circ} \mathrm{W}$ with $12-$ and $4-\mathrm{km}$ resolutions for the outer and inner domains configured with $122 \times 108$ and $220 \times 199$ grid points, respectively (Fig. 3). The model was initialized with 31 sigma levels in the vertical with nearly half of these levels below $800 \mathrm{mb}$ to properly analyze PBL evolution similar to Quintanar et al. (2009). The choice of physics options was based upon sensitivity tests and their ability to represent summertime atmospheric conditions for this region. The selection included Eta microphysics, Monin-Obukhov surface layer physics, the Noah LSM, and the Medium-Range Forecast (MRF) PBL scheme, which were similar to Quintanar et al. $(2008,2009)$ studies. The Noah LSM is a community land surface model developed by the NCEP, Oregon State
University, the U.S. Air Force, and the Hydrologic Research Laboratory (Mitchell 2001). This LSM has been tested against other widely used LSMs and reasonably reproduced surface fluxes, moisture, and temperature (Chen and Dudhia 2001b). In addition, it was implemented in the Leeper et al. (2009) land use-land cover change (LULCC) study over western Kentucky that included combined changes in land cover, vegetation fraction, and soil moisture. The Noah LSM consists of four layers with depths of $0.1,0.3,0.6$, and $1 \mathrm{~m}$ with a reservoir past $1 \mathrm{~m}$. In addition, Noah accounts for the movement of moisture through the soil by gravitation pull, capillarity action, and transpiration. It allows vegetation and soil type to vary as described by the U.S. Geological Survey (USGS), accounting for vegetation biophysical parameters (stomatal resistance, roughness, leaf area index, and rooting depth) and soil properties (heat capacity, wilting point, and hydraulic conductivity). The predominant soil type across the karst region is silty loam. For further information regarding the Noah LSM, please consult Chen and Dudhia (2001a).

In addition, model spinups were included for three events (of four), presented here in another study by Quintanar et al. $(2008,2009)$, and no notable disagreement was found between simulations with and without 
TABLE 1. Observed SCAN- and FNL-prescribed 0-5-cm depth initial soil moisture conditions over USGS-designated karst and nonkarst sites removed from the Mississippian flood plain and complex terrain of the Southeast United States for the 11 Jun 2006, 17 Jun 2006, 23 Jun 2006, and 29 Aug 2008 cases.

\begin{tabular}{|c|c|c|c|c|c|}
\hline Site name & Date & Type & $\operatorname{SCAN}\left(\mathrm{m}^{3} \mathrm{~m}^{-3}\right)$ & $\mathrm{FNL}\left(\mathrm{m}^{3} \mathrm{~m}^{-3}\right)$ & $\mathrm{FNL}-\mathrm{SCAN}\left(\mathrm{m}^{3} \mathrm{~m}^{-3}\right)$ \\
\hline \multirow[t]{4}{*}{ Mammoth Cave, KY } & 11 Jun 2006 & Karst & 0.155 & 0.357 & 0.202 \\
\hline & 17 Jun 2006 & Karst & 0.159 & 0.334 & 0.175 \\
\hline & 23 Jun 2006 & Karst & 0.163 & 0.351 & 0.188 \\
\hline & 29 Aug 2008 & Karst & 0.087 & 0.267 & 0.180 \\
\hline \multirow[t]{4}{*}{ Starkville, MS } & 11 Jun 2006 & Karst & 0.174 & 0.303 & 0.129 \\
\hline & 17 Jun 2006 & Karst & 0.166 & 0.303 & 0.137 \\
\hline & 23 Jun 2006 & Karst & 0.197 & 0.325 & 0.128 \\
\hline & 29 Aug 2008 & Karst & 0.444 & 0.344 & -0.100 \\
\hline \multirow[t]{4}{*}{ Eastview Farm, TN } & 11 Jun 2006 & Karst & 0.200 & 0.327 & 0.127 \\
\hline & 17 Jun 2006 & Karst & 0.174 & 0.316 & 0.142 \\
\hline & 23 Jun 2006 & Karst & 0.168 & 0.330 & 0.162 \\
\hline & 29 Aug 2008 & Karst & 0.326 & 0.350 & 0.024 \\
\hline \multirow[t]{4}{*}{ Point Remove, AR } & 11 Jun 2006 & Nonkarst & 0.143 & 0.270 & 0.127 \\
\hline & 17 Jun 2006 & Nonkarst & 0.123 & 0.276 & 0.153 \\
\hline & 23 Jun 2006 & Nonkarst & 0.228 & 0.296 & 0.068 \\
\hline & 29 Aug 2008 & Nonkarst & 0.257 & 0.298 & 0.041 \\
\hline \multirow[t]{4}{*}{ Goodwin, MS } & 11 Jun 2006 & Nonkarst & 0.149 & 0.299 & 0.150 \\
\hline & 17 Jun 2006 & Nonkarst & 0.139 & 0.282 & 0.143 \\
\hline & 23 Jun 2006 & Nonkarst & 0.174 & 0.329 & 0.155 \\
\hline & 29 Aug 2008 & Nonkarst & NA & 0.311 & NA \\
\hline \multirow[t]{4}{*}{ Hartselle, AL } & 11 Jun 2006 & Nonkarst & 0.195 & 0.312 & 0.117 \\
\hline & 17 Jun 2006 & Nonkarst & 0.190 & 0.303 & 0.113 \\
\hline & 23 Jun 2006 & Nonkarst & 0.188 & 0.318 & 0.130 \\
\hline & 29 Aug 2008 & Nonkarst & NA & 0.337 & NA \\
\hline
\end{tabular}

spinups. Based on these findings, since we are using the same convective events, and for efficient use of computational resources, model spinups were not included for the current experiments. Keeping in line with Quintanar et al. (2009), simulations in this study were initialized using the final analysis data (FNL) provided by NCEP at $1^{\circ} \times 1^{\circ}$ resolution.

Determination of dryness of karst soils compared to nonkarst was particularly challenging. Observationally, SM datasets were limited. Recently, the Natural Resource Conservation Service (NRCS) Soil Climate and Analysis Network (SCAN) has begun monitoring SM across the United States. Of the operational SCAN sites, there were two located in Kentucky (both over karst areas). Only one of these observing sites was active during the study period. These made comparisons of karst and nonkarst SM profiles over western Kentucky impossible. However, comparisons of FNL initial SM conditions for the four periods in this study revealed that observed soils at Mammoth Cave were drier than that of FNL, ranging between 0.175 and $0.202 \mathrm{~m}^{3} \mathrm{~m}^{-3}$ less than FNL (Table 1). In addition, comparisons of FNL-prescribed SM with other SCAN sites in adjacent regions showed that FNL had a moist SM bias (Table 1). It was found that all SCAN sites were drier than the FNL estimates (Table 1). Also, albeit very small, moist bias was greater for the FNL data when we compared them to karst sites (Table 2).

Given the uncertainty in SM variability over karst, an ensemble approach to simulate the effect of karst hydrology on initial SM conditions seemed reasonable. Based on the maximum $\left(0.167 \mathrm{~m}^{3} \mathrm{~m}^{-3}\right)$ and minimum $\left(0.03 \mathrm{~m}^{3} \mathrm{~m}^{-3}\right)$ karst-averaged FNL SM biases for the selected cases (Table 2), initial SM conditions over WKYPK were systematically increased and decreased by $0.05,0.10$, and $0.15 \mathrm{~m}^{3} \mathrm{~m}^{-3}$ to capture this range, creating both dry and wet ensembles. Simulated tests of diurnal, area-averaged ET (over WKYPK) revealed that the dry ensemble was less than control (CTRL) by $10 \%-20 \%$. This was in line with the Hess and White (1989b) 35-year water balance study over a portion of WKYPK, which noted a reduction in ET by $10 \%-13 \%$ over karst areas compared to the drainage basin average. This suggests the ensemble approach reasonably

TABLE 2. USGS-designated karst and nonkarst averages for the 11 Jun 2006, 17 Jun 2006, 23 Jun 2006, and 29 Aug 2008 cases.

\begin{tabular}{lcc}
\hline \hline Date & Karst $\left(\mathrm{m}^{3} \mathrm{~m}^{-3}\right)$ & Nonkarst $\left(\mathrm{m}^{3} \mathrm{~m}^{-3}\right)$ \\
\hline 11 Jun 2006 & 0.153 & 0.131 \\
17 Jun 2006 & 0.151 & 0.136 \\
23 Jun 2006 & 0.159 & 0.118 \\
29 Aug 2008 & 0.035 & 0.021 \\
\hline
\end{tabular}



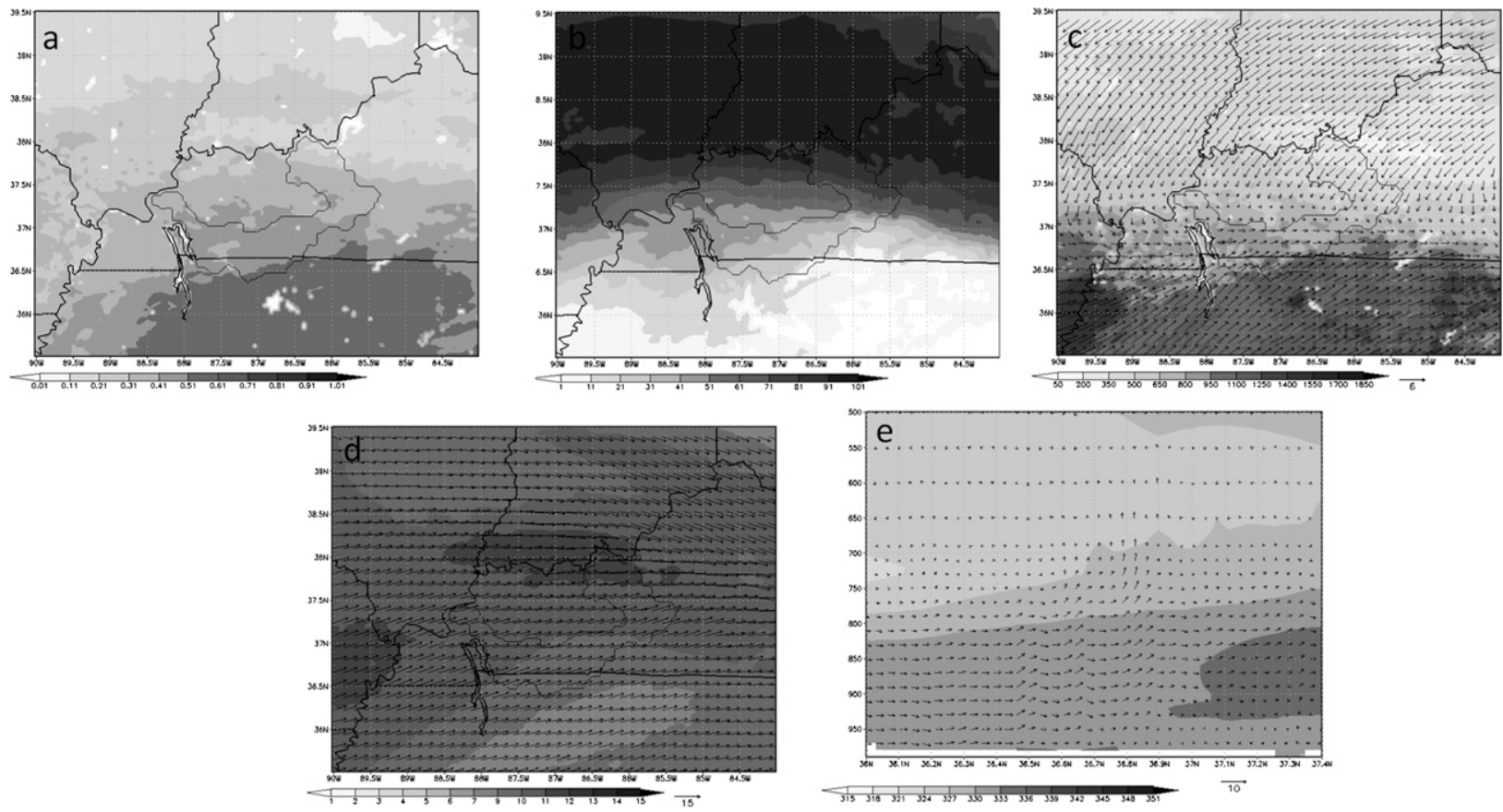

FIG. 4. Simulated (a) ET (fractions), (b) cloud cover (fractions), (c) PBL height (m) and 10-m wind ( $\mathrm{m} \mathrm{s}^{-1}$ ), (d) 800-hPa mixing ratio $\left(\mathrm{g} \mathrm{kg}^{-1}\right)$ and wind $\left(\mathrm{m} \mathrm{s}^{-1}\right)$, and (e) north-to-south vertical cross section of $\theta_{e}(\mathrm{~K})$ and vertical wind (cm s${ }^{-1}$ ) for the $11 \mathrm{Jun} 2006 \mathrm{CTRL}$ experiment.

captured the effect of karst on ET over WKYPK. SM was perturbed only initially and allowed to evolve over the 24-h simulation period. During this relatively short 24-h model integration, the signature of karst-perturbed soil moisture was persistent over time. Damping time scales of SM perturbations have been studied by Liu and Avissar (1999) with a simplified model similar to that used in the Biosphere-Atmosphere Transfer Scheme (BATS; Dickinson et al. 1993). They identified four time scales associated with soil moisture perturbations, including seasonal, monthly, weekly, and daily. Soil perturbations that persist on a daily time scale and interact with day-to-day synoptic systems are the focus of this study.

As noted above, we have conducted 24-h simulations for each case for a total of 28 different experiments. However, the data analysis presented here incorporates a 12-h daytime period from 1200 to 2400 UTC ( 6 a.m. to 6 p.m. local time) for each case. All four precipitationproducing convective events occurred during this $12-\mathrm{h}$ period. Three of the four events occurred in the afternoon and one occurred during the midmorning (23 June 2006). The initial data analysis suggested that the daytime hours produced the most interesting response to changes in land surface hydrologic conditions. As a result, our discussion presented below was focused on the daytime periods.

\section{Results}

\section{a. 11 June 2006 case}

\section{1) SYNOPTIC SETTING AND CONTROL SIMULATION}

The 11 June 2006 event was frontally forced with a stationary boundary located across the study area (NCEP 2009c). The sizeable ranges in CTRL daytime ET rate $\left(0-0.6 \mathrm{~mm} \mathrm{~h}^{-1}\right)$ and cloud cover $(0 \%-90 \%)$ were identified regions away from and along the frontal boundary (Figs. 4a,b). Dense cloud cover along the frontal boundary dampened PBL growth with heights ranging between $150 \mathrm{~m}$ near the front and $1650 \mathrm{~m}$ ahead of the boundary (Fig. 4c). Discontinuities in nearsurface wind speed $\left(2-5 \mathrm{~m} \mathrm{~s}^{-1}\right)$ and direction along the boundary were clearly evident with northeasterly winds north of the front and southwesterly flow to the south (Fig. 4c). Farther aloft $(800 \mathrm{hPa})$, winds were mainly from the west at $9-10 \mathrm{~m} \mathrm{~s}^{-1}$ with a mixing ratio ranging between 8 and $12 \mathrm{~g} \mathrm{~kg}^{-1}$, showing moisture convergence along the front (Fig. 4d). A south-to-north vertical cross section of diurnal-average $\theta_{e}$ indicated a moisture tongue above the surface (930-810 hPa) near the front over the northern half of the cross section with relatively weak convection (vertical motion) of 6-8 $\mathrm{cm} \mathrm{s}^{-1}$ (Fig. 4e). During this 24-h period, showers were noted over much 

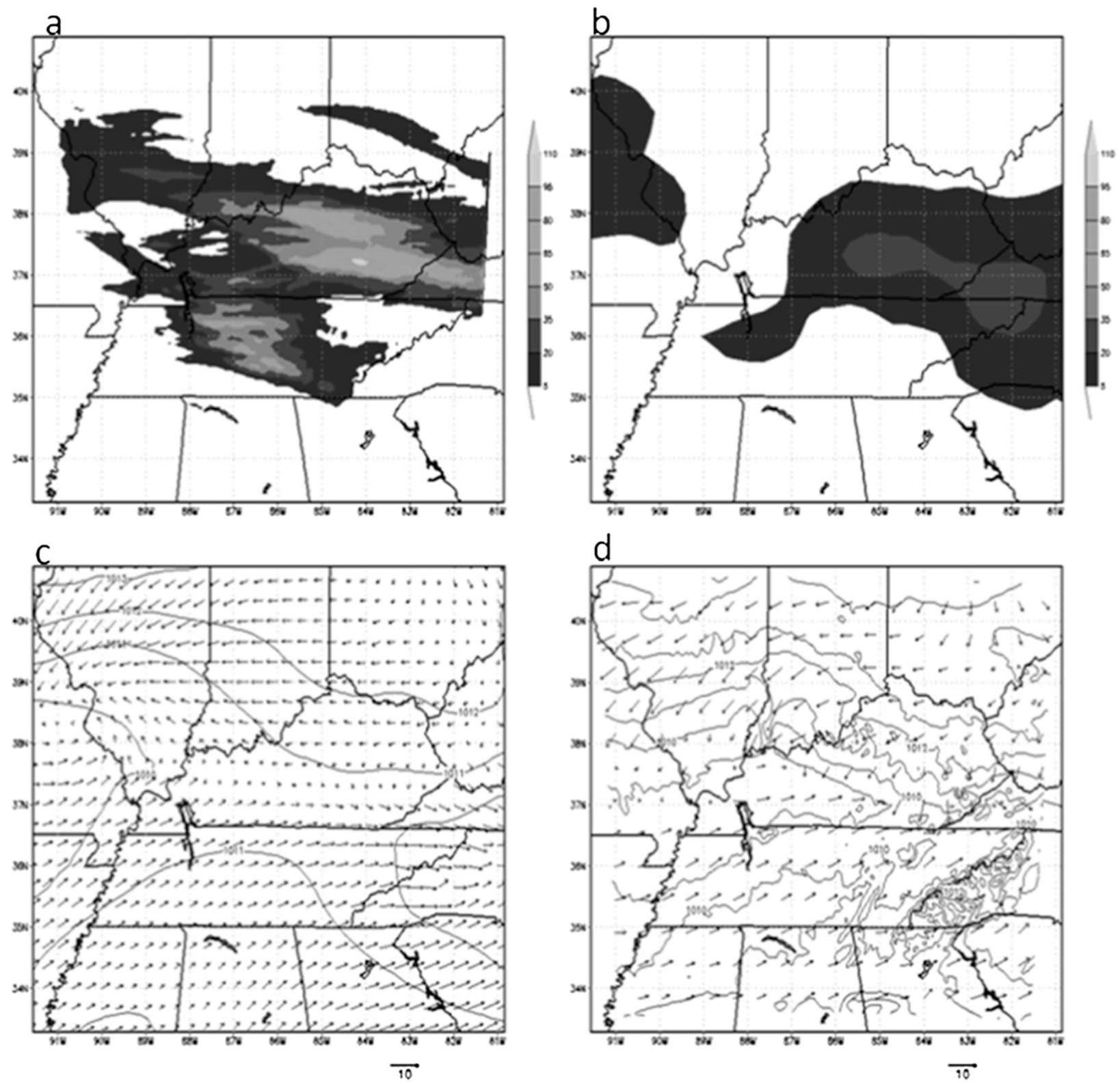

FIG. 5. (a),(c) CTRL and (b),(d) NARR (a),(b) accumulated rainfall (mm) and (c),(d) sea level pressure (hPa) with surface winds (m s ${ }^{-1}$ ) at noon on 11 Jun 2006.

of Kentucky and Tennessee in conjunction with the stationary frontal boundary with domain-average accumulated rainfall of $7.74 \mathrm{~mm}$ (Fig. 5a).

A comparison with the North American Regional Reanalysis (NARR; Mesinger et al. 2006) dataset (Fig. 5b) suggested that model-simulated results for the 11 June event were satisfactory. Accumulated precipitation shown in the NARR data was well captured by the model with a tendency to overestimate maximum rainfall and propagate the frontal boundary farther southward, initiating precipitation earlier over central Tennessee (Figs. 5a,b).
Snapshots taken from both NARR and CTRL simulations at noon showed that the model captured the overall trend in sea level pressure with matching southwesterly and easterly winds over Tennessee and Indiana, respectively (Figs. 5c,d). In short, these results suggest that the model was able to resolve atmospheric processes and simulated atmospheric fields for 11 June 2006 reasonably.

\section{2) DRY ENSEMBLE}

Modeled reductions in SM for the dry ensemble experiment altered PBL development, but had little impact 

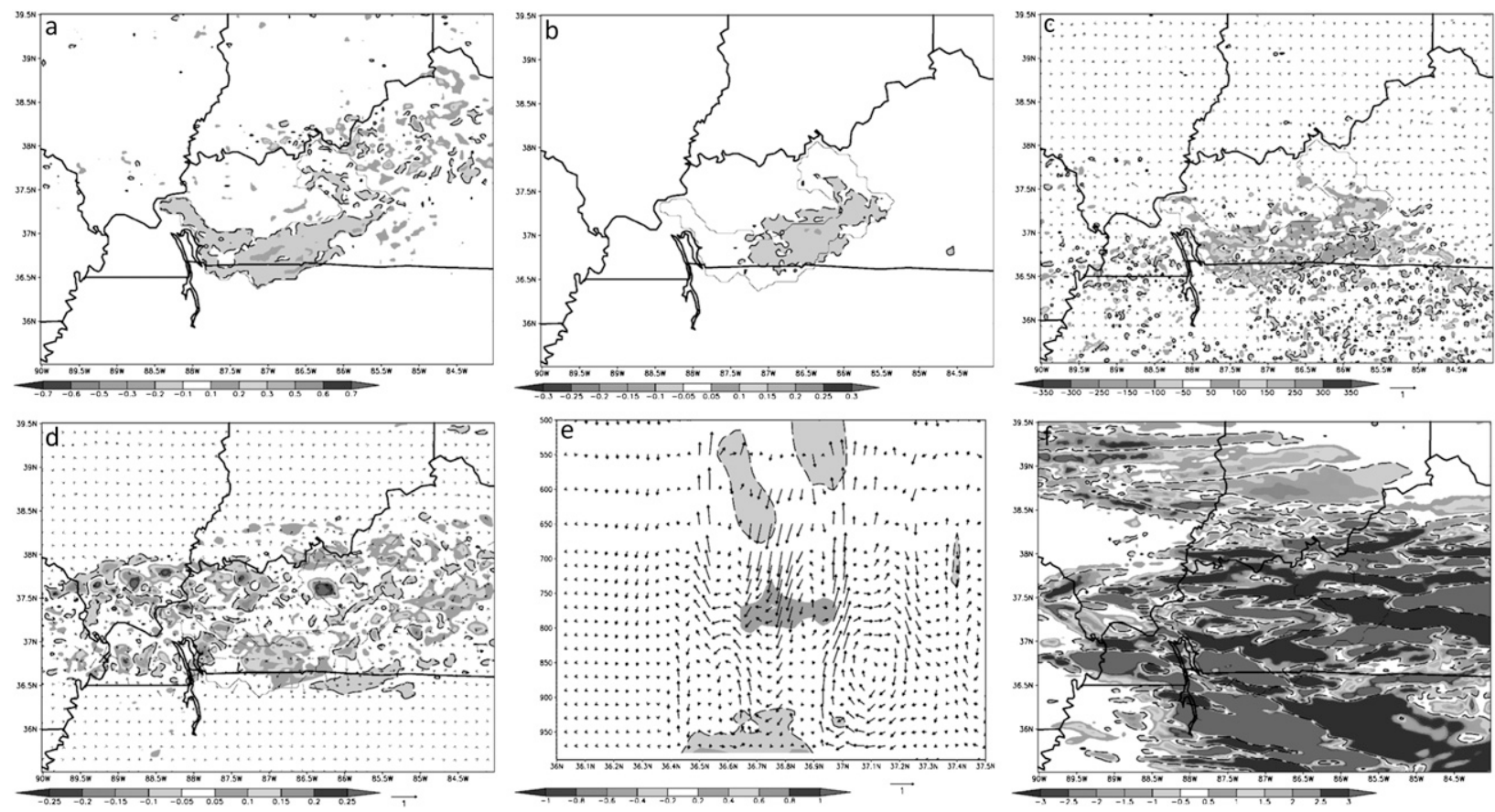

FIG. 6. Differences between the 11 Jun 2006 dry ensemble and CTRL for (a) ET (fractions), (b) cloud cover (fractions), (c) PBL height (m) and surface wind $\left(\mathrm{m} \mathrm{s}^{-1}\right)$, (d) 800-hPa mixing ratio $\left(\mathrm{g} \mathrm{kg}^{-1}\right)$ and wind $\left(\mathrm{m} \mathrm{s}^{-1}\right)$, (e) north-to-south vertical cross section of $\theta_{e}(\mathrm{~K})$ and vertical wind $\left(\mathrm{cm} \mathrm{s}^{-1}\right)$, and $(\mathrm{f})$ accumulated rainfall $(\mathrm{mm})$. Areas of negative values are bounded by broken lines (- - -).

on synoptic-scale features. Compared to CTRL, lowering of SM reduced modeled ET (Fig. 6a) over karst by $10 \%-20 \%$, which is in line with Hess and White (1989b). These results suggest that the dry ensemble experiment can be used as a realistic proxy for simulating karst behavior within the WRF. Reductions in modeled ET resulted in reduced cloud cover $(5 \%-10 \%)$ and increased PBL heights $(50-300 \mathrm{~m}$ ) over karst (Figs. 6b,c). Along with PBL height changes, latent and sensible heat fluxes were decreased and increased up to 30 and $23 \mathrm{~W} \mathrm{~m}^{-2}$ compared to CTRL, respectively (Table 3 ). These changes are in line with Mahmood et al. (2011) and Leeper et al. (2009). Surface wind vector differences showed convergence along karst areas. In addition, compared to CTRL, wind speed was about $0.5 \mathrm{~m} \mathrm{~s}^{-1}$ lower (Fig. 6c). Also, 800-hPa wind field differences showed a slight change in mean wind over karst landscape (about $0.5 \mathrm{~m} \mathrm{~s}^{-1}$ ), which redistributed low-level moisture along the frontal boundary with mixing ratio differences both less and greater than CTRL by 0.25 and $0.30 \mathrm{~g} \mathrm{~kg}^{-1}$, respectively (Fig. $6 \mathrm{~d}$ ). Vertical $\theta_{e}$ differences (Fig. 6e) compared to CTRL showed two regions of distinct change. Between the surface and $960 \mathrm{mb}, \theta_{e}$ differences were less than CTRL over karst by $0.3-0.5 \mathrm{~K}$ because of reduced ET rates. At $800 \mathrm{hPa}, \theta_{e}$ differences were greater than CTRL by $0.2-0.4 \mathrm{~K}$ because of entrainment of moist air aloft. In addition, this moist air was shifted slightly northward of the lower $\theta_{e}$ near the surface (Fig. 6e) and a mesoscale circulation developed along the northern edge of karst (Fig. 6e). The modifications in PBL evolution, including near-surface and low-level wind flow, convection, and cloud cover, altered the distribution of simulated rainfall along the frontal boundary shown in Fig. 6.

\section{3) Wet ENSEMBLE}

Model sensitivity to increased soil moisture for the 11 June case was suppressed because of already-moist soil conditions. Modeled ET and cloud cover were sporadically enhanced over karst by $10-20$ and $2 \%-8 \%$ compared to CTRL, respectively (Figs. 7a,b). Modifications in PBL heights over moist karst compared to CTRL were mixed with both increases and decreases of 50 $150 \mathrm{~m}$ (Fig. 7c). However, most areas experienced lowering of height. Again, latent and sensible heat fluxes were increased and decreased up to 11 and $9 \mathrm{~W} \mathrm{~m}^{-2}$ compared to CTRL, respectively (Table 3 ). Near-surface diurnal-average wind vector differences with respect to CTRL showed small changes in mean flow over karst with wind speed differences of $0.15-0.6 \mathrm{~m} \mathrm{~s}^{-1}$. Above the PBL, 800-mb wind field differences were also small. There was a small reduction in mixing ratio compared to CTRL (0.05-0.20 $\mathrm{g} \mathrm{kg}^{-1}$ ) (Fig. 7d) over moist karst. A vertical cross section and wind field differences indicated 
TABLE 3. Karst region averages and ranges of latent and sensible flux for control and dry and wet ensembles.

\begin{tabular}{ccc}
\hline $\begin{array}{c}\text { Convective } \\
\text { cases }\end{array}$ & $\begin{array}{c}\text { Latent heat } \\
\text { (range) }\left(\mathrm{W} \mathrm{m}^{-2}\right)\end{array}$ & $\begin{array}{c}\text { Sensible heat } \\
\text { (range) }\left(\mathrm{W} \mathrm{m}^{-2}\right)\end{array}$ \\
\hline 11 Jun CTRL & 266 & 64 \\
Dry ensemble & $236(216-254)$ & $87(74-101)$ \\
Wet ensemble & $277(274-280)$ & $55(53-58)$ \\
17 Jun CTRL & 283 & 55 \\
Dry ensemble & $245(218-269)$ & $84(67-103)$ \\
Wet ensemble & $298(293-303)$ & $43(40-47)$ \\
23 Jun CTRL & 242 & 55 \\
Dry ensemble & $212(191-229)$ & $73(62-85)$ \\
Wet ensemble & $256(251-260)$ & $48(46-50)$ \\
29 Aug CTRL & 213 & 69 \\
Dry ensemble & $157(109-194)$ & $105(80-136)$ \\
Wet ensemble & $239(229-248)$ & $53(48-60)$ \\
\hline
\end{tabular}

elevated $\theta_{e}$ by $0.1-0.4 \mathrm{~K}$ from the surface up to $975 \mathrm{hPa}$ with a region of strong subsidence centered over karst (Fig. 7e). In addition, this region of subsidence completes 2 circulation cells on both southern and northern edges of karst. Similar to the dry ensemble, the distribution of modeled rainfall along the frontal boundary was slightly modified (Fig. 7f).

\section{b. 17 June 2006 case}

\section{1) SYNOPTIC SETTING AND CONTROL SIMULATION}

The 17 June case was a nonfrontal convective event (NCEP 2009b). Simulated diurnal averages of modeled
ET and cloud cover ranged between $0-0.6 \mathrm{~mm} \mathrm{~h}^{-1}$ and $0 \%-90 \%$, respectively (not shown). PBL heights ranged between 300 and $1500 \mathrm{~m}$ across the study area with a strong southerly surface wind with speeds of $7 \mathrm{~m} \mathrm{~s}^{-1}$. Between the surface and $800 \mathrm{mb}$, there were southerly winds of $8-15 \mathrm{~m} \mathrm{~s}^{-1}$ with very little directional shear, which is indicative of a low-level jet. The southerly flow advected moisture with a mixing ratio between 5 and $10.5 \mathrm{~g} \mathrm{~kg}^{-1}$. A vertical cross section of $\theta_{e}$ along the center of the study region showed a moisture tongue just above the surface at $975 \mathrm{mb}$ extending up to $790 \mathrm{mb}$ in conjunction with the low-level jet. Further analysis indicates this jet became stronger with time, extending into the evening hours. Simulated rainfall during the 24-h period mainly fell over northwestern Illinois.

Rainfall over western Tennessee and Kentucky was underestimated (not shown) partially because of moderate capping and the inability of the explicit convection scheme to resolve precipitation shown in the NARR data. In addition, simulated rainfall over northern Illinois was initiated earlier than observed with the model propagating the frontal boundary further eastward sooner, as was the case for the 11 June event. However, surface winds and sea level pressure were captured well by the model.

\section{2) DRY ENSEMBLE}

Modeled results for the 17 June case was more sensitive to reductions in SM over karst than 11 June. Simulated
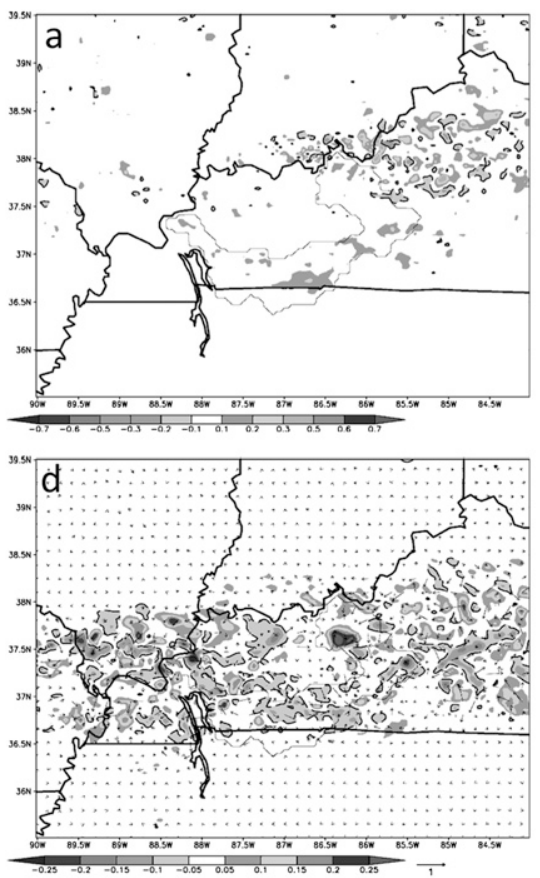
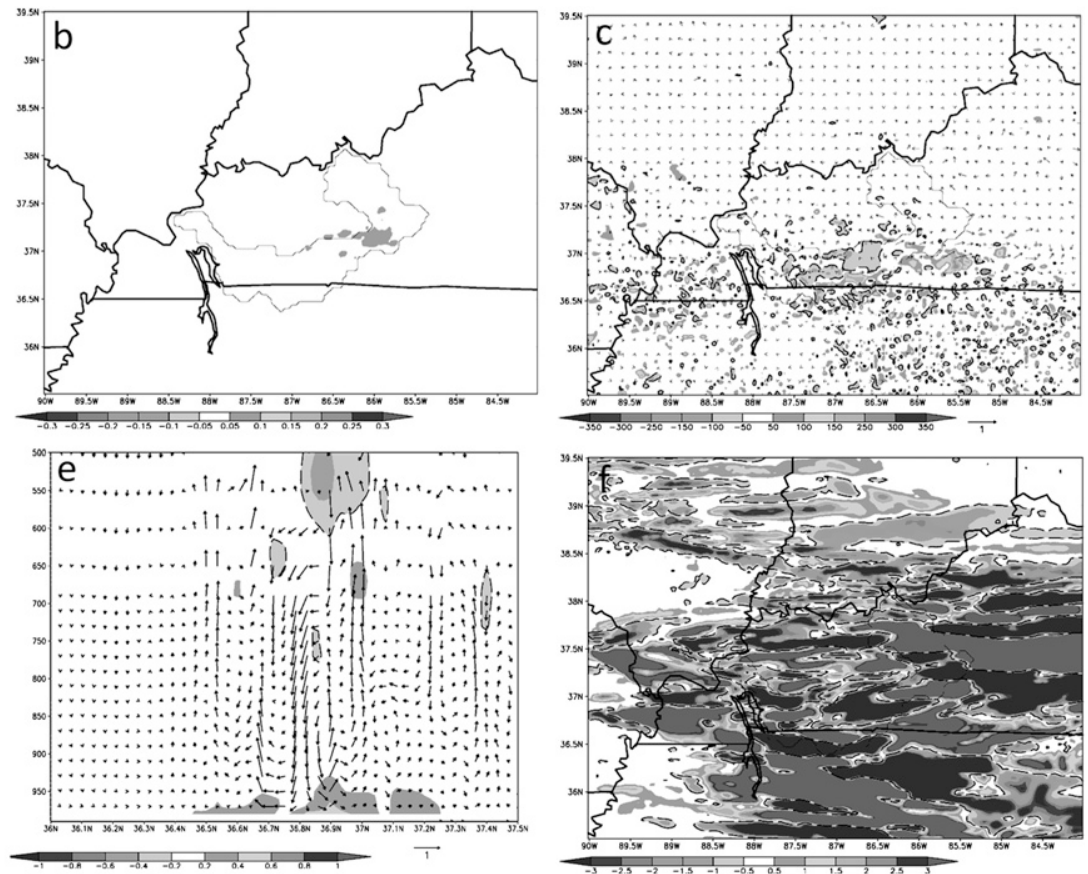

FIG. 7. As in Fig. 6, but for differences between wet ensemble and CTRL. 

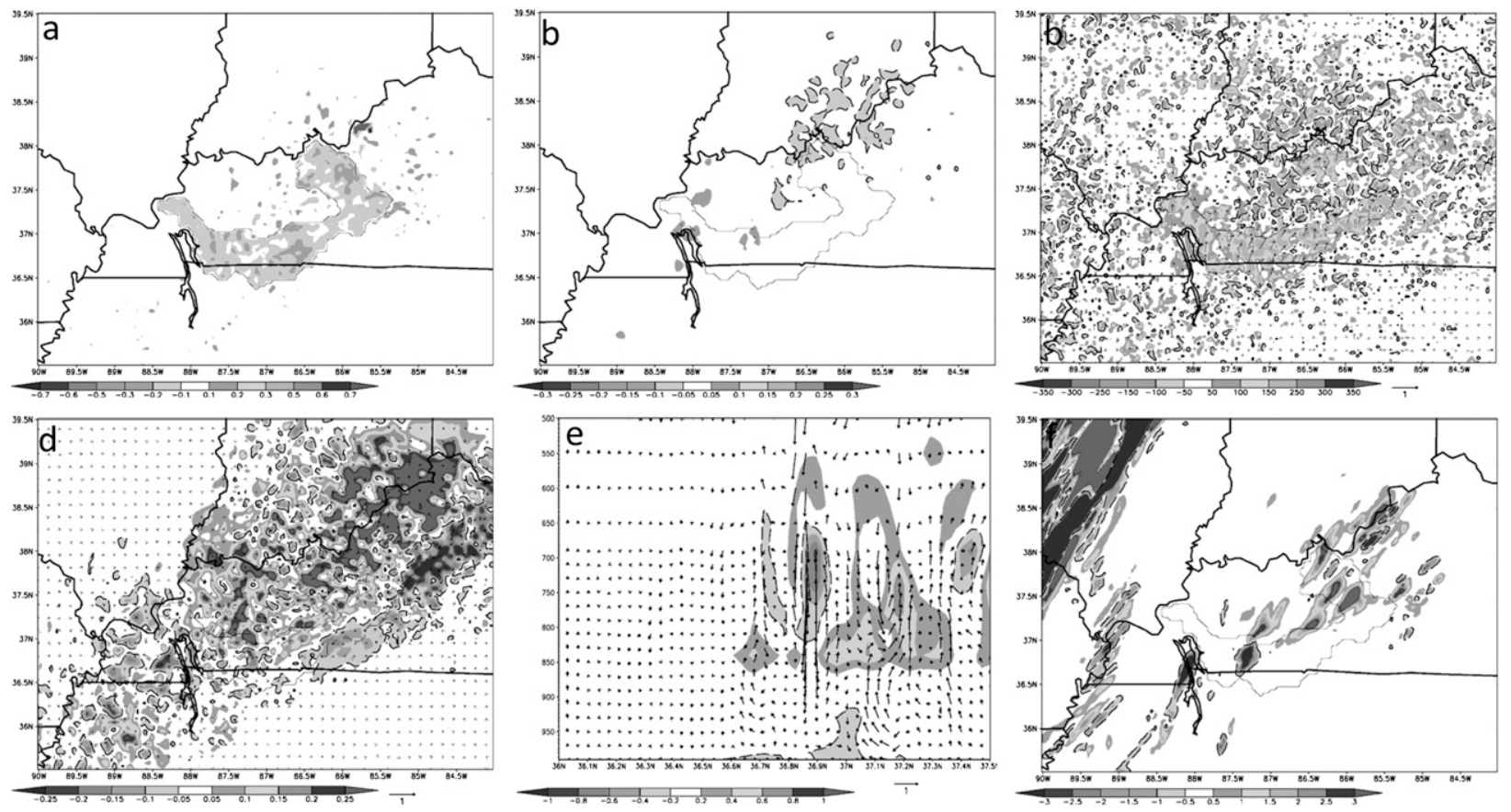

FIG. 8. As in Fig. 6, but for 17 Jun 2006.

diurnal averages of ET over dry karst were reduced by $10 \%-20 \%$ (Fig. 8a). This resulted in reduced cloud cover compared to CTRL, downwind of dry karst, by $5 \%-10 \%$ over northern Kentucky and Indiana but increased cloud cover over western portions of the karst region by $5 \%-10 \%$ (Fig. $8 \mathrm{~b}$ ). The increase in cloud cover was due to low-level-jet-driven moisture advection into a region of increased vertical mixing over drier soils. This was complemented by higher PBL heights than CTRL by $50-300 \mathrm{~m}$ over and downwind of the karst region (Fig. 8c). Latent and sensible heat fluxes were decreased and increased up to 38 and $29 \mathrm{~W} \mathrm{~m}^{-2}$ compared to CTRL, respectively (Table 3 ). In addition, near-surface wind speeds were greater than CTRL over dry karst by about $1 \mathrm{~m} \mathrm{~s}^{-1}$ because of differential heating along the karst boundary that created a region of convection along the northern edge of karst. Similarly, 800-mb wind speeds were greater than CTRL by $0.5 \mathrm{~m} \mathrm{~s}^{-1}$ with an increasing mixing ratio downwind of karst landscape up to $0.5 \mathrm{~g} \mathrm{~kg}^{-1}$ (Fig. 8d). A vertical profile of $\theta_{e}$ differences showed a slightly drier PBL by $0.2-0.4 \mathrm{~K}$ from the surface up to $920 \mathrm{mb}$ (Fig. 8e). Vertical wind field differences nicely depicted the region of convection along the northern edge of karst, as previously mentioned. This convection initiated light precipitation in several locations downwind of dry karst over central Kentucky (Fig. 8f). Additional showers developed upwind of karst over western Tennessee and Kentucky as well. The inclusion of drier soils over
WKYPK improved the spatial distribution of simulated rainfall. As expected, it was less than NARR totals.

\section{3) Wet ENSEMBLE}

Diurnal averages of ET for the wet ensemble were sporadically greater than CTRL by $10 \%-20 \%$ with localized regions of up to $30 \%$ (Fig. 9a). This increase in ET elevated cloud cover downwind of karst areas by $5 \%-10 \%$ greater than CTRL in some locations (Fig. 9b). However, over karst, changes in diurnal averages of cloud cover were minimal. The increase in atmospheric moisture from elevated ET rates reduced PBL heights compared to CTRL by $50-150 \mathrm{~m}$ (Fig. 9c). Latent and sensible heat fluxes were increased and decreased up to 15 and $12 \mathrm{~W} \mathrm{~m}^{-2}$ compared to CTRL, respectively (Table 3). In addition, moist soils over wet karst reduced surface southerly wind speed by about $1 \mathrm{~m} \mathrm{~s}^{-1}$ because of changes in surface pressure gradients (not shown) (Fig. 9d). The reduction in mean wind flow reduced moisture advection and slightly lowered mixing ratio downwind of karst areas compared to CTRL. The vertical cross section of $\theta_{e}$ for the wet ensemble showed little change compared to CTRL over wet karst (Fig. 9e). Vertical wind field differences also varied slightly with changes in convection (mainly subsidence) over wet karst compared to CTRL. Simulated precipitation downwind of karst was slightly enhanced but not as widespread as the dry ensemble because of suppressed convection (Fig. 9f). However, the wet ensemble initiated rainfall 

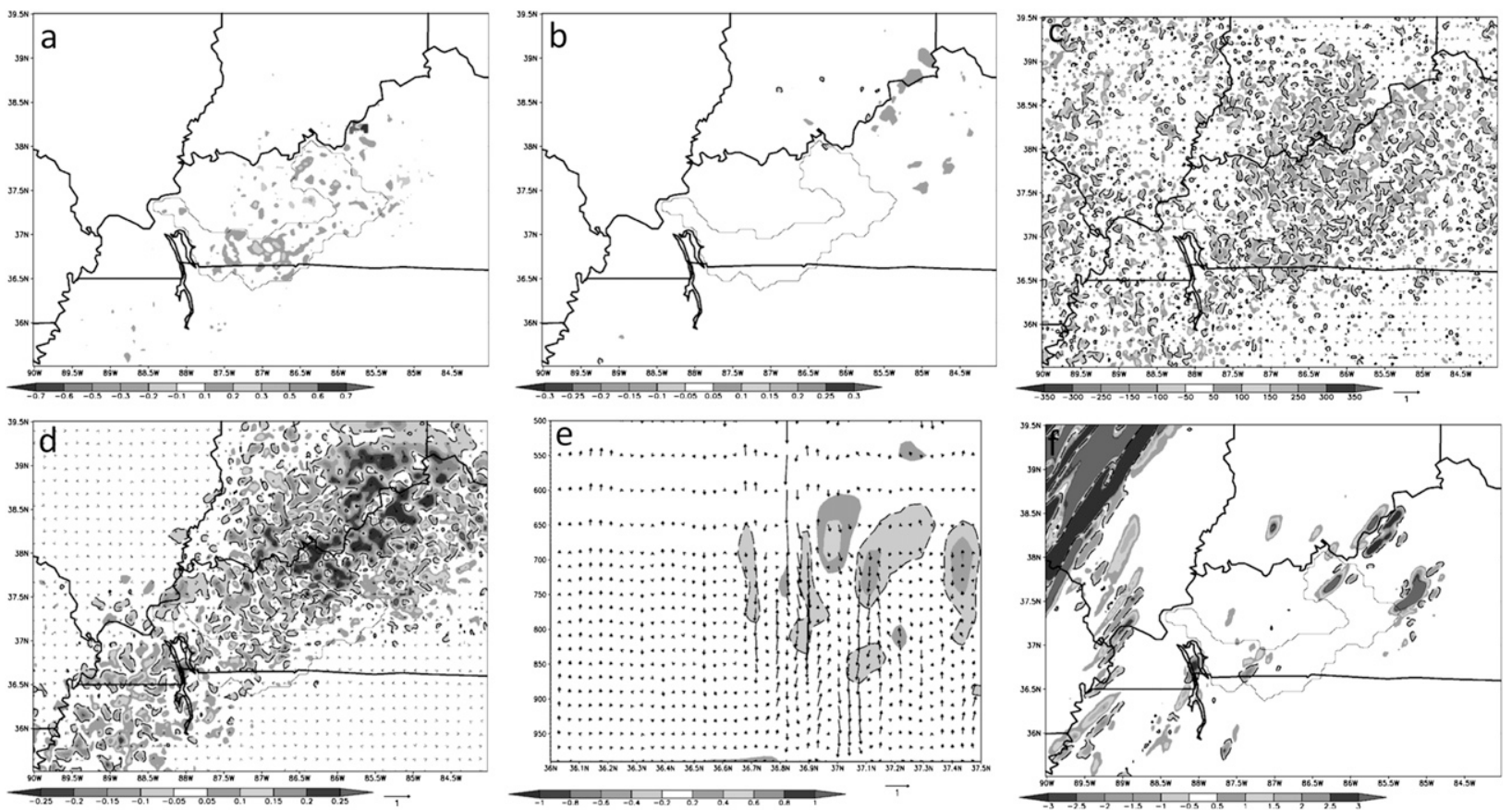

FIG. 9. As in Fig. 6, but for 17 Jun 2006 and the wet ensemble.

upwind of karst similar to the dry ensemble with an improvement in rainfall over western Tennessee and Kentucky compared to CTRL.

\section{c. 23 June 2006 case}

\section{1) SYNOPTIC SETTING AND CONTROL SIMULATION}

The 23 June case was identified as a frontally forced convection event (NCEP 2009a). CTRL ET rates during this period were relatively low compared to other selected cases because of dense cloud cover. It was found that the ET rates ranged between 0 and $0.4 \mathrm{~mm} \mathrm{hr}^{-1}$ and cloud cover between $70 \%$ and $90 \%$ (not shown). PBL heights ranged between 150 and $1350 \mathrm{~m}$ with a discontinuity in surface wind speed and direction along the front. Winds north of the front were from the northeast and veered to the southwest over the southern half of the study region with speeds near $5 \mathrm{~m} \mathrm{~s}^{-1}$. At $800 \mathrm{mb}$, southwesterly wind with speeds of $10 \mathrm{~m} \mathrm{~s}^{-1}$ brought plenty of moisture into the region with mixing ratio ranging between 6 and $11 \mathrm{~g} \mathrm{~kg}^{-1}$. A south-to-north vertical cross section of $\theta_{e}$ showed a moist southern half from the surface up to $840 \mathrm{mb}$ with a moisture tongue extending northward in the direction of upper-level winds (not shown). During this 24-h period, precipitation was initiated along the Ohio River in northern to eastern Kentucky, and from central Tennessee to the Appalachian range with domain-average rainfall of $2.81 \mathrm{~mm}$. The distribution of CTRL rainfall for this period was quite similar to NARR data (not shown). In addition, a snapshot from noon showed CTRL surface winds and sea level pressure were also similar to NARR data.

\section{2) DRY ENSEMBLE}

Reductions in SM over karst for the 23 June case impacted some regions of the study area away from dry karst as a result of changes in the timing and pattern of precipitation. For instance, diurnal averages of modeled ET rates were reduced over karst by $10 \%-30 \%$ with additional changes along the Ohio River and central Tennessee compared to CTRL (Fig. 10a). Diurnal averages of cloud cover fractions were similar to CTRL over most of the areas (Fig. 10b). However, PBL height differences were greater than CTRL by $50-250 \mathrm{~m}$ over dry karst (Fig. 10c). It was also found that latent and sensible heat flux were decreased and increased up to 30 and $18 \mathrm{~W} \mathrm{~m}^{-2}$ compared to CTRL (Table 3), respectively. In addition, near-surface wind vector differences showed convergence over dry karst, with alterations in mean flow. Similarly, 800-mb wind vector differences showed modified mean wind over southeastern dry karst (Fig. 10d), allowing for upper-level moisture to converge over this region compared to CTRL. A north-to-south vertical cross section of $\theta_{e}$ differences depicted a slightly drier PBL compared to CTRL from the surface up to $900 \mathrm{mb}$ with moister air aloft (Fig. 10e). Vertical wind field differences showed weak circulations on both southern and northern edges of karst areas with mainly rising 

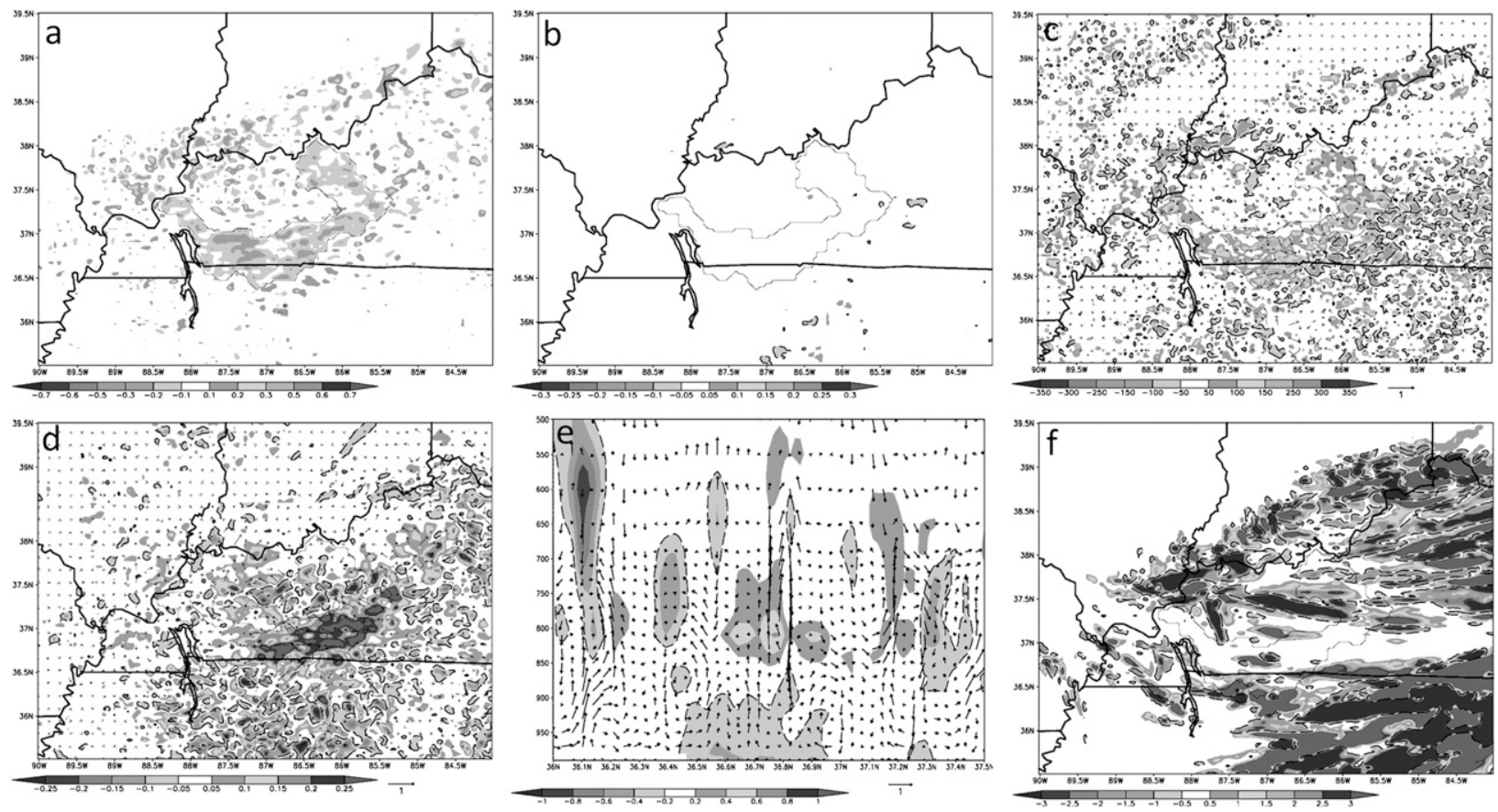

FIG. 10. As in Fig. 6, but for 23 Jun 2006.

motion over karst (Fig. 10e). Simulated rainfall for the dry ensemble was similar to CTRL, producing showers over western Kentucky (Fig. 10f). However, additional showers were simulated for the southwestern edge of WKYPK and this was in agreement with NARR.

\section{3) Wet ensemble}

Increased soil moisture over karst for the 23 June case impacted PBL processes, but these changes compared to CTRL were more localized than simulated changes for the dry ensemble. Diurnal-average ET over karst for the wet ensemble was greater than CTRL by $10 \%-$ $30 \%$ (Fig. 11a). Elsewhere (nonkarst), diurnal-average differences in ET were affected because of differences in modeled and CTRL rainfall. Despite the increase in modeled ET over wet karst, simulated cloud cover was comparable to CTRL (Fig. 11b). Over wet karst, PBL heights were generally $50-150 \mathrm{~m}$ lower compared to CTRL (Fig. 11c). In addition, latent and sensible heat flux were increased and decreased up to 14 and $7 \mathrm{~W} \mathrm{~m}^{-2}$ compared to CTRL, respectively. Near-surface wind differences between wet karst and CTRL was small with maximum differences collocated with the largest change in PBL height. Differences between wet ensemble and CTRL winds at $800 \mathrm{mb}$ were also small. This subsequently reduced the mixing ratio for the wet ensemble (Fig. 11d). The $\theta_{e}$ differences along a south-to-north cross section were slightly greater than CTRL from the surface to $980 \mathrm{mb}$ (Fig. 11e). Vertical wind field differences showed a fairly well-developed circulation along the southern edge of karst. Modifications to rainfall patterns were generally similar to the dry ensemble. However, wet ensemble produced less rainfall along the southwestern edge of WKYPK (Fig. 11f).

\section{d. 29 August 2008 case}

\section{1) SyNOPTIC SETTING AND CONTROL SIMULATION}

The 29 August 2008 case was frontally forced (NCEP 2009d) with drier initial soil conditions compared to the June cases. During this 24 -h period, a weak stationary frontal boundary moved across the study region. CTRL diurnal-average ET rates were less to the north and increased southward with a range of $0.1-0.5 \mathrm{~mm} \mathrm{~h}^{-1}$. These results were in line with dense cloud cover to the north $(90 \%)$, which was thinned southeastward (1\%). Diurnal averages of PBL heights ranged between 300 and $1100 \mathrm{~m}$ with surface wind vectors showing cyclonic rotation wrapping around the low-pressure system to the north at speeds of roughly $4 \mathrm{~m} \mathrm{~s}^{-1}$. The $800-\mathrm{mb}$ wind vectors were northwesterly across the study region with wind speeds near $8 \mathrm{~m} \mathrm{~s}^{-1}$. Low-level moisture $(800 \mathrm{mb})$ clearly indicated convergence of moisture along the frontal boundary with the mixing ratio ranging between 5.5 to the east of the front and $11 \mathrm{~g} \mathrm{~kg}^{-1}$ along the front. Along a south-to-north vertical cross section over karst, higher $\theta_{e}$ was modeled over the northern half with $\theta_{e}$ ranging between 330 and $337 \mathrm{~K}$ from the surface up to 

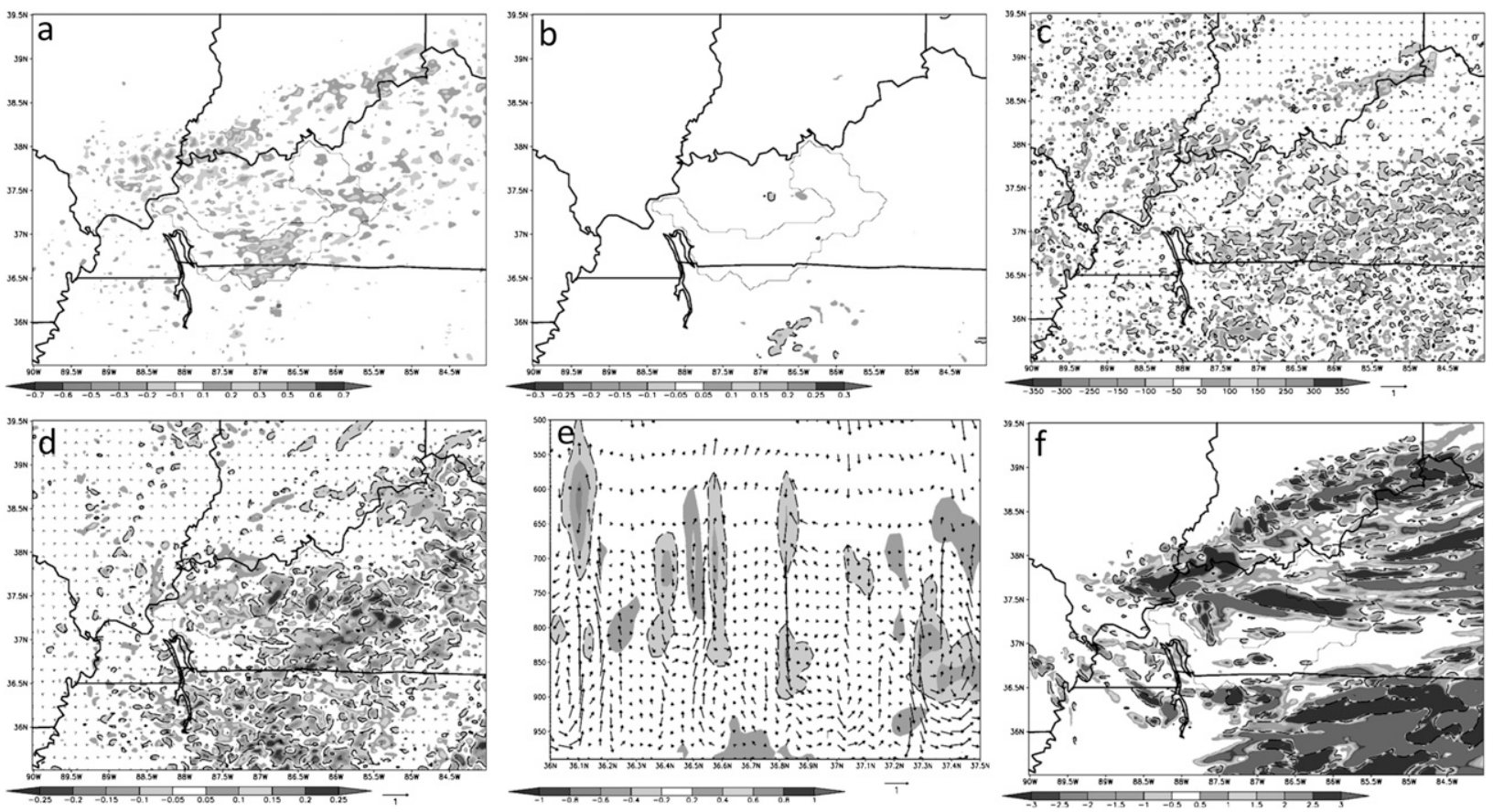

FIG. 11. As in Fig. 6, but for 23 Jun 2006 and the wet ensemble.

$700 \mathrm{mb}$. Winds were mainly from the north at $3-5 \mathrm{~m} \mathrm{~s}^{-1}$. CTRL precipitation and surface winds were in agreement with the NARR data. Isolated rainfall over northern Kentucky along the Ohio River, central Tennessee, and eastern Kentucky were captured well by the CTRL simulation (not shown). However, the model slightly underestimated the area-average rainfall compared to the NARR data. In addition, snapshots of surface wind and sea level pressure shows that they were also in agreement with the NARR data.

\section{2) DRY ENSEMble}

Modeled PBL evolution was sensitive to reductions in soil moisture over dry karst. Simulated ET rates were diminished by $20 \%-50 \%$ compared to CTRL (Fig. 12a). In addition, low-level cloud cover reduced by $2 \%-10 \%$ downwind of karst (Fig. 12b). This is similar to the 11 June case. PBL heights for the dry ensemble were greater than CTRL over karst by $50-350 \mathrm{~m}$ with converging surface wind vector differences toward karst reducing mean flow (Fig. 12c). Similar results were also noted at $800 \mathrm{mb}$ with wind vector differences modifying mean flow over karst compared to CTRL. This allowed low-level moisture to converge over karst with mixing ratio greater than CTRL by $0.1-0.4 \mathrm{~g} \mathrm{~kg}^{-1}$ (Fig. 12d). Note that latent and sensible heat flux were decreased and increased up to 56 and $36 \mathrm{~W} \mathrm{~m}^{-2}$ compared to CTRL, respectively. A vertical cross section of $\theta_{e}$ differences, expectedly, revealed reduced atmospheric moisture over karst from surface up to $860 \mathrm{mb}$. However, further aloft differences reversed with $\theta_{e}$ and they were greater than CTRL because of moisture convergence at this level (Fig. 12e). In addition, vertical wind field differences indicated the development of circulations along the soil moisture discontinuity boundary. Compared to CTRL, the dry experiments redistributed rainfall by suppressing all modeled precipitation downwind of karst (central Kentucky) (Fig. 12f). Also, dry experiments produced accumulated rainfall more similar to NARR (which we expected).

\section{3) Wet ENSEMBLE}

For the 29 August case, the model was more sensitive to increases in SM than in previous cases because of initial drier soils. Simulated ET rates over karst were greater than CTRL by $10 \%-30 \%$ (Fig. 13a). Despite increased ET, modeled cloud cover over karst was similar to CTRL (Fig. 13b). PBL heights for the wet ensemble were less than CTRL by $50-150 \mathrm{~m}$ with slightly diverging surface wind vector differences altering mean flow mainly along the eastern edge of karst (Fig. 13c). At $800 \mathrm{mb}$, wind vector differences were also very small compared to CTRL (Fig. 13d). In addition, the mixing ratio over karst was reduced compared to CTRL by 0.1$0.3 \mathrm{~g} \mathrm{~kg}^{-1}$ because of subsidence. Latent and sensible heat flux were decreased and increased up to 26 and $16 \mathrm{~W} \mathrm{~m}^{-2}$, respectively. A vertical cross section showed small increase in $\theta_{e}$ compared to CTRL near the surface 

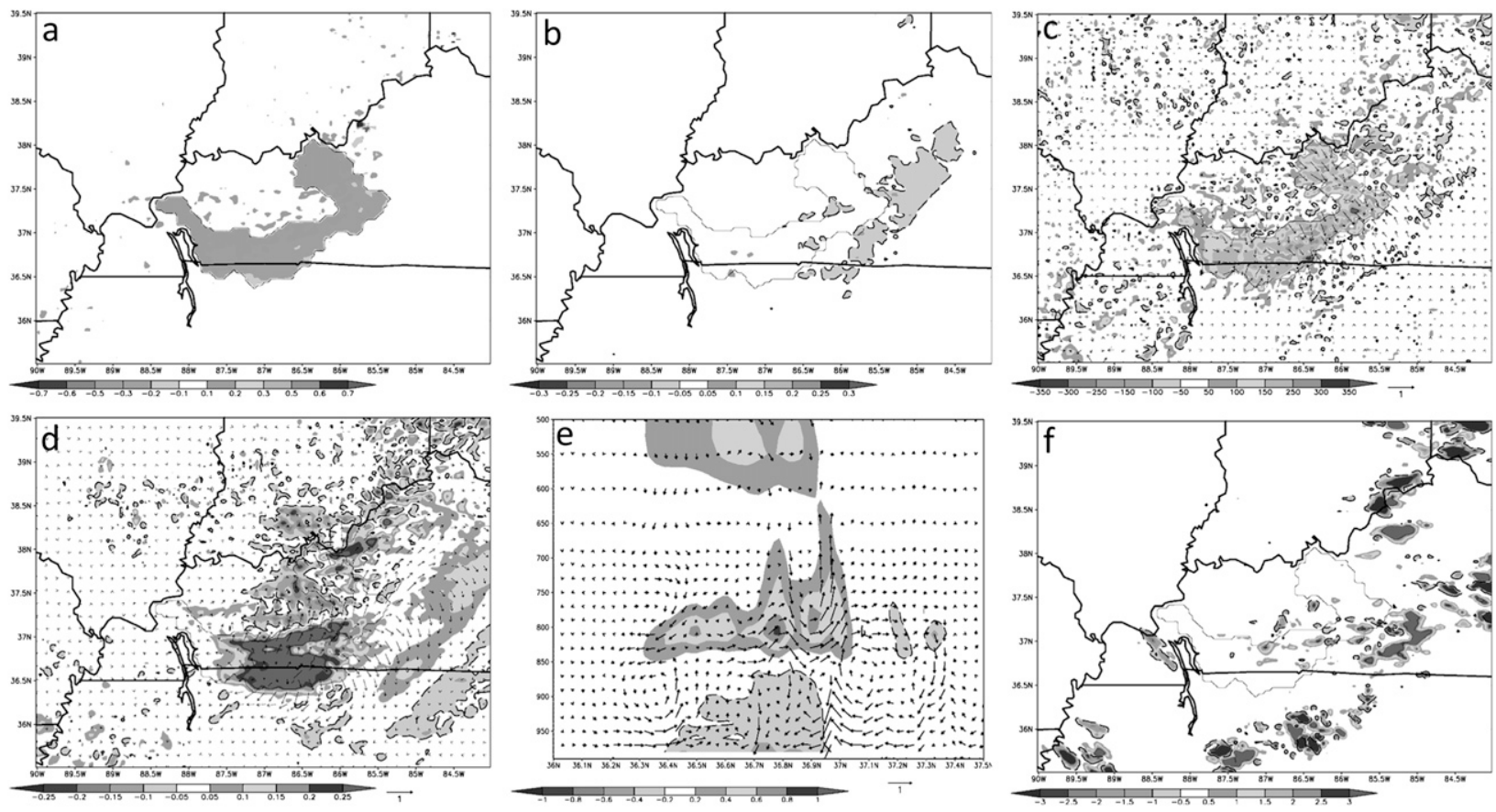

FIG. 12. As in Fig. 6, but for 29 Aug 2008.

in conjunction with subsiding low-level vertical wind vector differences (Fig. 13e). In addition, vertical wind vector differences revealed a well-developed circulation on the northern edge of karst, which generated light convective showers. Overall, simulated precipitation was enhanced over the eastern edge of the WKYPK (Fig. 13f).

\section{Discussion and concluding remarks}

The purpose of this study was to investigate the importance of local hydrological influences, such as karst, on PBL atmosphere evolution and modeled rainfall. It was found that changes in SM over WKYPK altered modeled PBL evolution, low-level wind fields, convection, and the distribution of atmospheric moisture for a series of typical summertime convective events. However, the sensitivity of simulated rainfall to modifications in soil moisture over WKYPK was controlled by the status of SM and synoptic conditions. Modeled rainfall for nonfrontal (17 June 2006) and weakly forced frontal (28 August 2008) events tended to be more sensitive to soil moisture perturbations than the strongly forced fontal events (11 June and 23 June 2006). In addition, changes in soil moisture conditions for dry simulations over WKYPK tended to improve the distribution of modeled rainfall when compared to NARR, and more so for the nonfrontal (17 June 2006) than the frontally forced (11 June 2006, 23 June 2006, and 29 August 2008) cases.
As previously suggested by Findell and Eltahir (2003), the impact of SM on atmospheric processes was sensitive to the initial state of the atmosphere. For instance, the role of modified SM in the initiation and development of precipitation was more obvious for the nonfrontal convective case (17 June) than any of the frontal convective cases (11 June, 23 June, and 29 August). For the nonfrontal event (17 June), reduced cloud cover resulted in increased solar radiation and enhanced differential heating between the two regions because of SM contrasts (karst and nonkarst). Subsequently, this has initiated increased convection and produced localized rainfall. In other words, the nonconvective event was more sensitive to changes in SM. Frontally forced convective events also responded to the changes in SM over karst areas. We have found changes in the mesoscale atmospheric circulation, location of precipitation, and thermodynamic characteristics. However, it also needs to be noted that the atmosphere was predisposed for development of convection due to frontal forcing.

Convective development along karst was organized into preferential regions of convection that were sensitive to background wind. Based on the results of this study, we suggest that over drier soils, preferential regions of convection would develop along the downwind edge of the karst-nonkarst boundary while the opposite is true (upwind) for moist karst ensembles (Fig. 14). Furthermore, these preferential convective regions affected horizontal surface and low-level $(800 \mathrm{mb})$ wind 

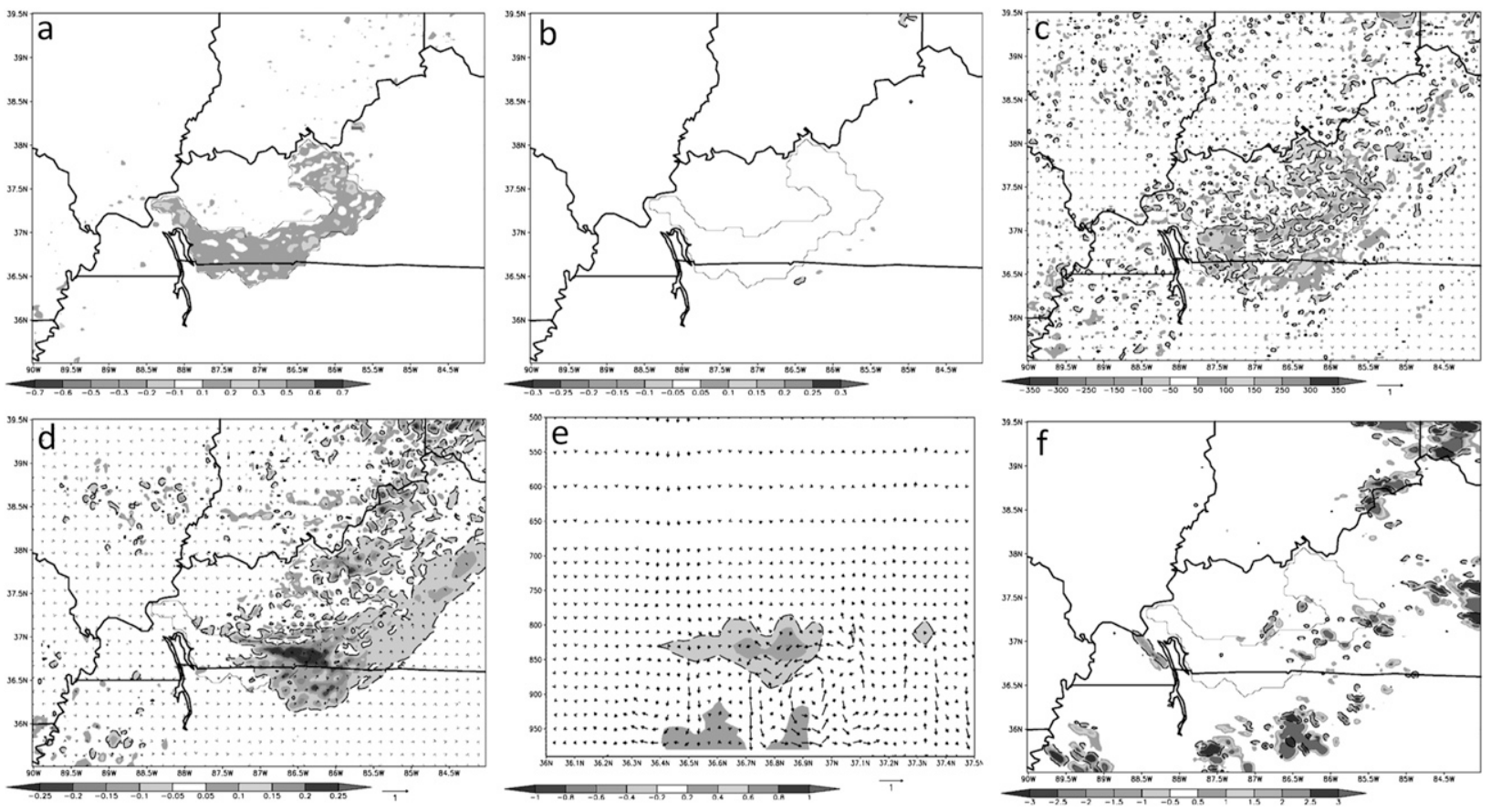

FIG. 13. As in Fig. 6, but for 29 Aug 2008 and the wet ensemble.

fields, leading to shifts in moisture convergence and precipitation patterns found in all cases considered in this study (spatiotemporal changes). However, these changes led to little or no change in total accumulation compared to CTRL, but in some instances, as previously mentioned, improved the distribution of rainfall compared to NARR. In addition, vertical wind field differences revealed the existence of mesoscale circulations along sharp boundaries in SM similar to Ookouchi et al. (1984) and Chen and Avissar (1994). These circulations in some instances initiated precipitation otherwise not modeled in CTRL.

To the authors' knowledge, this research is a first attempt to include the impact of karst in a numerical weather prediction model. While perturbing SM to mimic the influence of karst hydrology is not fully representative of the complex karstic processes, it was found that this simpler approach reasonably approximated observed reductions in ET rates between karst and nonkarst regions as noted by Hess and White (1989b) and Crowther (1987). In addition, while the present research is a firstorder approximation of the impact of karst on PBL atmosphere, modeled results highlighted the significance of karst as a local hydrological feature that can impact atmospheric processes and calls for additional research.

It should also be noted that future research should explore methods for realistically representing soil moisture variability over karst by focusing on localized discrete changes near karst surface features instead of broad alterations in soil moisture over a well-known karst region such as WKYPK. In addition, interdisciplinary research between atmospheric and karst studies is encouraged to develop a karst aquifer model that accounts for the local-scale surface and subsurface karst features as suggested by White (2002). These types of scientific investigations would require exhaustive field campaigns, but when implemented within atmospheric research models, they can provide insights for both atmospheric and hydrological science communities.

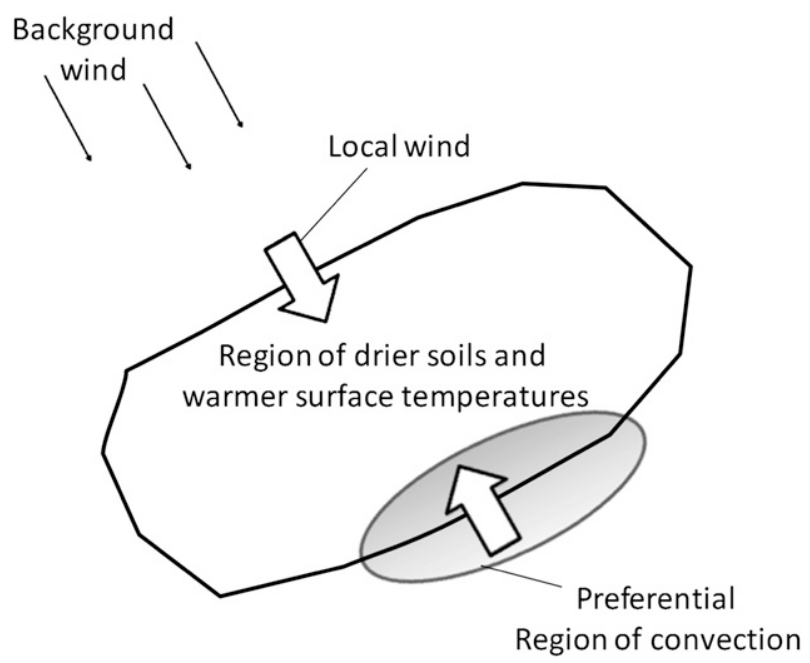

FIG. 14. An illustration of local and background winds creating a region of preferential convection on the downwind-leeward side of a karst (dry) soil region. 
Acknowledgments. The authors thank the editor and three anonymous reviewers for their valuable comments and suggestions, which helped to improve this paper. The authors also gratefully acknowledge valuable feedback provided by Dr. Jason Polk and Dr. Chris Groves on karst hydrology. This work is funded by the USDA Grant 58-6445-6-068. Technical assistance provided by Michael Grogan and Andrew Quilligan is much appreciated.

\section{REFERENCES}

Brubaker, K. L., D. Entekhabi, and P. S. Eagleson, 1993: Estimation of continental precipitation recycling. J. Climate, 6, 10771089.

Brutsaert, W., 2005: Hydrology: An Introduction. Cambridge University Press, $605 \mathrm{pp}$.

Chang, J.-T., and P. J. Wetzel, 1991: Effects of spatial variations of soil moisture and vegetation on the evolution of a prestorm environment: A numerical case study. Mon. Wea. Rev., 119, 1368-1390.

Chen, F., and R. Avissar, 1994: Impact of land-surface moisture variability on local shallow convective cumulus and precipitation in large-scale models. J. Appl. Meteor., 33, 1382-1401.

, and J. Dudhia, 2001a: Coupling an advanced land surfacehydrology model with the Penn State-NCAR MM5 modeling system. Part I: Model implementation and sensitivity. Mon. Wea. Rev., 129, 569-585.

$\longrightarrow$, and $\longrightarrow$, 2001b: Coupling an advanced land surfacehydrology model with the Penn State-NCAR MM5 modeling system. Part II: Preliminary model validation. Mon. Wea. Rev., 129, 587-604.

Clark, C. A., and R. W. Arritt, 1995: Numerical simulations of the effect of soil moisture and vegetation cover on the development of deep convection. J. Appl. Meteor., 34, 2029-2045.

Crowther, J., 1987: Ecological observations in tropical karst terrain, West Malaysia. III. Dynamics of the vegetation-soilbedrock system. J. Biogeogr., 14, 157-164.

Cubbage, J. C., 1981: Hydrology of the sinking creek system, Logan and Simpson Counties, Kentucky. M.S. thesis, Dept. of Geography and Geology, Western Kentucky University, 83 pp.

Currens, J. C., 2002: Kentucky is karst country! What should you know about sinkholes and springs. Kentucky Geological Survey Information Circular 4, 29 pp.

Daoxian, Y., 1988: On the karst environmental system. Proc. 21st Congress of the International Association of Hydrogeologists, Guilin, China, IAH, 30-46.

De Vries, J. J., and I. Simmers, 2002: Groundwater recharge: An overview of processes and challenges. Hydrogeol. J., 10, 5-17.

Dickinson, R. E., A. Henderson-Sellers, and P. J. Kennedy, 1993: Biosphere-Atmosphere Transfer Scheme (BATS) version 1E as coupled to the NCAR Community Climate Model. NCAR Tech. Note NCAR/TN-387+STR, 72 pp.

Dirmeyer, P. A., F. J. Zeng, A. Ducharne, J. C. Morrill, and R. D. Koster, 2000: The sensitivity of surface fluxes to soil water content in three land surface schemes. J. Hydrometeor., 1, 121-134.

Douville, H., F. Chauvin, and H. Broqua, 2001: Influence of soil moisture on the Asian and African monsoons. Part I: Mean monsoon and daily precipitation. J. Climate, 14, 2381-2403.

Ewe, S. M. L., L. S. L. Sternberg, and D. E. Busch, 1999: Water-use patterns of woody species in pineland and hammock communities of south Florida. For. Ecol. Manage., 18, 139-148.
Findell, K. L., and E. A. B. Eltahir, 2003: Atmospheric controls on soil moisture-boundary layer interactions: Three-dimensional wind effects. J. Geophys. Res., 108, 8385, doi:10.1029/2001JD001515.

Goldscheider, N., D. Drew, and S. Worthington, 2007: Introduction. Methods in Karst Hydrology, N. Goldscheider and D. Drew, Eds., Taylor \& Francis, 1-8.

Grasso, L. D., 2000: A numerical simulation of dryline sensitivity to soil moisture. Mon. Wea. Rev., 128, 2816-2834.

Groves, C., 2007: Hydrological methods. Methods in Karst Hydrol$o g y$, N. Goldscheider and D. Drew, Eds., Taylor \& Francis, 45-64.

_ 2008: Water resource challenges in karst regions of southwest China. J. L. Turner, Ed., China Environment Series, No. 9, Woodrow Wilson International Center for Scholars, 139-148.

_ C. Bolster, and J. Meiman, 2005: Spatial and temporal variations in epikarst storage and flow in south central Kentucky's Pennyroyal Plateau sinkhole plain. U.S. Geological Survey Scientific Investigations Rep. 2005-5160, 64-73.

Gulden, L. E., E. Rosero, Z.-L. Yang, M. Rodell, C. S. Jackson, G.-Y. Niu, P.J.-F. Yeh, and J. Famiglietti, 2007: Improving land-surface model hydrology: Is an explicit aquifer model better than a deeper soil profile. Geophys. Res. Lett., 34, L09402, doi:10.1029/2007GL029804.

Hess, J. W., and W. B. White, 1989a: Chemical hydrology. Karst Hydrology: Concepts from the Mammoth Cave Area, W. B. White and E. L. White, Eds., Van Nostrand Reinhold, 145-174.

- and - 1989b: Water budget and physical hydrology. Karst Hydrology: Concepts from the Mammoth Cave Area, W. B. White and E. L. White, Eds., Van Nostrand Reinhold, 65-99.

_ S. G. Wells, J. F. Quinlan, and W. B. White, 1989: Hydrology of the south-central Kentucky karst. Karst Hydrology: Concepts from the Mammoth Cave Area, W. B. White and E. L. White, Eds., Van Nostrand Reinhold, 15-63.

Huang, J., H. M. van den Dool, and K. P. Georgarakos, 1996: Analysis of model-calculated soil moisture over the United States (1931-1993) and applications to long-range temperature forecasts. J. Climate, 9, 1350-1362.

Jiang, X., G.-Y. Niu, and Z.-L. Yang, 2009: Impacts of vegetation and groundwater dynamics on warm season precipitation over the central United States. J. Geophys. Res., 114, D06109, doi:10.1029/2008JD010756

Leeper, R., R. Mahmood, and A. I. Quintanar, 2009: Near surface atmospheric response to simulated changes in land-cover, vegetation fraction, and soil moisture over western Kentucky. Publ. Climatol., 62, 1-41.

LeMone, M. A., F. Chen, J. G. Alfieri, M. Tewari, B. Geerts, Q. Miao, R. L. Grossman, and R. L. Coulter, 2007: Influence of land cover and soil moisture on horizontal distribution of sensible and latent heat fluxes in southeast Kansas during IHOP 2002 and CASES-97. J. Hydrometeor., 8, 68-87.

Liu, Y., and R. Avissar, 1999: A study of persistence in the landatmosphere system with a fourth-order analytical model. J. Climate, 12, 2154-2168.

Lyons, T. J., 2002: Clouds prefer native vegetation. Meteor. Atmos. Phys., 80, 131-140.

Mahmood, R., R. Leeper, and A. I. Quintanar, 2011: Sensitivity of planetary boundary layer atmosphere to historical and future changes of land use/land cover, vegetation fraction, and soil moisture in western Kentucky, USA. Global Planet. Change, 78, 36-53, doi:10.1016/j.gloplacha.2011.05.007.

McCumber, M. C., and R. A. Pielke, 1981: Simulation of the effects of surface fluxes of heat and moisture in a mesoscale numerical model. J. Geophys. Res., 86, 9929-9938. 
McPherson, R. A., 2007: A review of vegetation-atmosphere interactions and their influences on mesoscale phenomena. Prog. Phys. Geogr., 31, 261-285.

Mesinger, F., and Coauthors, 2006: North American regional reanalysis. Bull. Amer. Meteor. Soc., 87, 343-360.

Milanović, P. T., 1981: Karst Hydrogeology. Water Resources Publications, $434 \mathrm{pp}$.

Mitchell, K., 2001: The community Noah Land-Surface Model (LSM) user's guide, public release version 2.2. National Centers for Environmental Protection, 25 pp. [Available online at ftp://ftp.ncep.noaa.gov/pub/gcp/ldas/noahlsm/ver_2.2.]

NCEP, cited 2009a: Daily weather maps: Friday June 23, 2006 [Available online at http://www.hpc.ncep.noaa.gov/dailywxmap/ index_20060623.html.]

_ _ cited 2009b: Daily weather maps: Saturday June 17, 2006. [Available online at http://www.hpc.ncep.noaa.gov/dailywxmap/ index_20060617.html.]

_ , cited 2009c: Daily weather maps: Sunday June 11, 2006. [Available online at http://www.hpc.ncep.noaa.gov/dailywxmap/ index_20060611.html.]

_ [Available online at http://www.hpc.ncep.noaa.gov/dailywxmap/ index_20080829.html.]

Ookouchi, Y., M. Segal, R. C. Kessler, and R. A. Pielke, 1984: Evaluation of soil moisture effects on the generation and modification of mesoscale circulations. Mon. Wea. Rev., 112, 2281-2292.

Pan, Z., E. Takle, M. Segal, and R. Turner, 1996: Influences of model parameterization schemes on the response of rainfall to soil moisture in the central United States. Mon. Wea. Rev., 124, 1786-1802.

Pielke, R. A., 2001: Influence of the spatial distribution of vegetation and soils on the prediction of cumulus convective rainfall. Rev. Geophys., 39, 151-177.

Pitman, A. J., 2003: Review: The evolution of, and revolution in, land surface schemes designed for climate models. Int. J. Climatol., 23, 479-510.

Polk, J. S., 2009: Proxy records of climate change in subtropical and tropical karst environments. Ph.D. dissertation, University of South Florida, 629 pp.
- P. E. Beynen, and P. P. Reader, 2007: Late Holocene environmental reconstruction using cave sediments from Belize. Quat. Res., 68, 58-68.

Quintanar, A., R. Mahmood, J. Loughrin, and N. C. Lovanh, 2008: A coupled MM5-Noah land surface model-based assessment of sensitivity of planetary boundary layer variables to anomalous soil moisture conditions. Phys. Geogr., 29, 54-78, doi:10.2747/0272-3646.29.1.54

,-- M. V. Motley, J. Yan, J. Loughrin, and N. C. Lovanh, 2009: Simulation of boundary layer trajectory dispersion sensitivity to soil moisture conditions: MM5 and Noah-based investigation. Atmos. Environ., 43, 3774-3785.

Schlosser, C. A., and P. C. D. Milly, 2002: A model-based investigation of soil moisture predictability and associated climate predictability. J. Hydrometeor., 3, 483-501.

Veni, G., H. DuChene, N. C. Crawford, C. G. Groves, G. N. Huppert, E. H. Kastning, R. Olson, and B. J. Wheeler, 2001: Living with Karst: A Fragile Foundation. American Geological Institute Environmental Awareness Series, Vol. 4, AGI, 64 pp.

Wang, S.-J., Q.-M. Liu, and D.-F. Zhang, 2004: Karst rocky desertification in southwestern China: Geomorphology, landuse, impact and rehabilitation. Land Degrad. Dev., 15, 115-121.

White, W. B., 1989: Introduction to the karst hydrology of the Mammoth Cave area. Karst Hydrology: Concepts from the Mammoth Cave Area, W. B. White and E. L. White, Eds., Van Nostrand Reinhold, 1-13.

2002: Karst hydrology: Recent developments and open questions. Eng. Geol., 65, 85-105.

WRF, cited 2009: WRF model version 3.1. [Available online at http://www.mmm.ucar.edu/wrf/users/wrfv3.1/wrf_model.html.]

Yeh, P.J.-F., and E. A. B. Eltahir, 2005: Representation of water table dynamics in a land surface scheme. Part I: Model development. J. Climate, 18, 1861-1880.

York, J. P., M. Person, W. J. Gutowski, and T. C. Winter, 2002: Putting aquifers into atmospheric simulation models: An example from the Mill Creek Watershed, northeastern Kansas. Adv. Water Resour., 25, 221-238.

Zhang, D., and R. A. Anthes, 1982: A high-resolution model of the planetary boundary layer-Sensitivity tests and comparisons with SESAME-79 data. J. Appl. Meteor., 21, 1594-1609. 